\title{
Experimental study into the petrogenesis of crystal-rich basaltic to andesitic magmas at Arenal volcano
}

\author{
F. Parat $\cdot$ M. J. Streck $\cdot$ F. Holtz $\cdot$ R. Almeev
}

\begin{abstract}
Arenal volcano is nearly unique among arc volcanoes with its 42 year long (1968-2010) continuous, small-scale activity erupting compositionally monotonous basaltic andesites that also dominate the entire, $\sim 7000$ year long, eruptive history. Only mineral zoning records reveal that basaltic andesites are the result of complex, open-system processes deriving minerals from a variety of crystallization environments and including the episodic injections of basalt. The condition of the mafic input as well as the generation of crystal-rich basaltic andesites of the recent, 1968-2010, and earlier eruptions were addressed by an experimental study at $200 \mathrm{MPa}, 900-1,050{ }^{\circ} \mathrm{C}$, oxidizing and fluid-saturated conditions with various fluid compositions $\left[\mathrm{H}_{2} \mathrm{O} /\left(\mathrm{H}_{2} \mathrm{O}+\mathrm{CO}_{2}\right)=0.3-1\right]$. Phase equilibria were determined using a phenocryst-poor ( $3 \mathrm{vol} \%)$ Arenal-like basalt $\left(50.5-\mathrm{wt} \% \mathrm{SiO}_{2}\right)$ from a nearby scoria cone containing olivine $\left(\mathrm{Fo}_{92}\right)$, plagioclase $\left(\mathrm{An}_{86}\right)$, clinopyroxene $(\mathrm{Mg \#}=82)$ and magnetite $\left(\mathrm{X}_{\mathrm{ulvö}}=0.13\right)$. Experimental melts generally reproduce observed compositional trends among Arenal samples. Small differences between experimental melts and natural rocks can be explained by opensystem processes. At low pressure (200 MPa), the mineral
\end{abstract}

Communicated by Jochen Hoefs.

F. Parat $(\square)$

Géosciences Montpellier, Université Montpellier 2,

Place E. Bataillon, 34095 Montpellier cedex 5, France

e-mail: fleurice.parat@gm.univ-montp2.fr

M. J. Streck

Department of Geology, Portland State University, Portland,

OR 97207-0751, USA

F. Holtz $\cdot$ R. Almeev

Institut für Mineralogie, Leibniz Universität Hannover,

Callinstrasse 3, 30167 Hannover, Germany assemblage as well as the mineral compositions of the natural basalt were reproduced at $1,000{ }^{\circ} \mathrm{C}$ and high water activity. The residual melt at these conditions is basaltic andesitic $\left(55 \mathrm{wt} \% \mathrm{SiO}_{2}\right.$ ) with $5 \mathrm{wt} \% \mathrm{H}_{2} \mathrm{O}$. The evolution to more evolved magmas observed at Arenal occurred under fluid-saturated conditions but variable fluid compositions. At $1,000{ }^{\circ} \mathrm{C}$ and $200 \mathrm{MPa}$, a decrease of water content by approximately $1 \mathrm{wt} \%$ induces significant changes of the mineral assemblage from olivine + clinopyroxene + plagioclase ( $5 \mathrm{wt} \% \mathrm{H}_{2} \mathrm{O}$ in the melt) to clinopyroxene + plagioclase + orthopyroxene $\left(4 \mathrm{wt} \% \mathrm{H}_{2} \mathrm{O}\right.$ in the melt). Both assemblages are observed in crystal-rich basalt (15 vol\%) and basaltic andesites. Experimental data indicate that the lack of orthopyroxene and the presence of amphibole, also observed in basaltic andesitic tephra units, is due to crystallization at nearly water-saturated conditions and temperatures lower than $950{ }^{\circ} \mathrm{C}$. The enigmatic two compositional groups previously known as low- and high- $\mathrm{Al}_{2} \mathrm{O}_{3}$ samples at Arenal volcano may be explained by low- and high-pressure crystallization, respectively. Using high- $\mathrm{Al}$ as signal of deeper crystallization, first magmas of the 1968-2010 eruption evolved deep in the crust and ascent was relatively fast leaving little time for significant compositional overprint by shallower level crystallization.

Keywords Basaltic andesite $\cdot$ Arenal $\cdot$ Phase equilibria . Experiments $\cdot$ Subduction

\section{Introduction}

Arenal volcano belongs to a small group of arc volcanoes undergoing multi-decade long activities. Its eruption that started in 1968 came just recently ( 2010) to an end. Over these 42 years, Arenal erupted basaltic andesitic magmas 
that had remained nearly constant in composition (Reagan et al. 1987; Streck et al. 2005; Ryder et al. 2006). Basaltic andesite is also the magma type that dominates the entire eruptive stratigraphy of Arenal volcano since its inception 7,000 years ago (Borgia et al. 1988; Bolge et al. 2006). Only a few eruptions throughout its history produced basaltic and andesitic bulk compositions. Despite the compositional homogeneity among basaltic andesites of the 1968-2010 and of earlier eruptive periods, minerals and melt inclusions record a complex open-system evolution in which steady state production of the erupted basaltic andesitic magma is linked to episodic injections of basalt into the Arenal magma reservoir system (Streck et al. 2002). The compositional monotony of basaltic andesitic Arenal magmas implies that fractionation, recharge, ascent and eruption are well balanced in order for magmas to be essentially uniform while containing phenocrysts with different growth histories at the time of eruption. The few eruptions of basalt do indicate that basalt magma is present at depth from which basaltic andesitic magmas evolve. On the other hand, eruptions of crystal-poor andesitic/dacitic magma indicate that magma differentiation of basaltic andesitic magmas is ongoing as well beneath Arenal.

In this paper, we present new high-temperature and high-pressure experiments on a natural crystal-poor basalt from a nearby vent to Arenal volcano. Crystallization experiments have been designed to determine the pre-eruptive conditions of basalt and basaltic andesitic magmas at depth and to constrain the influence of physical conditions on phase equilibria, mineral and melt proportions, and the composition of equilibrium mineral phases (closed system). The results are used to constrain the depth of magma storage, to evaluate crystallization environments of naturally occurring phase assemblages, and to discuss the role of the prevailing fluid phase. Furthermore, we discuss the meaning of our results for processes involved during opensystem magma evolution of mafic to more felsic magma with the production of near steady state whole rock compositions over decadal time scales at Arenal volcano.

\section{Arenal volcano}

Eruptive history and products

Arenal is a small, dominantly basaltic andesitic composite volcano. Activity onset is between $~ 4000$ (Melson 1984) and 2,900 years B.P. (Borgia et al. 1988) but more recently 7,000 years (Soto et al. 1998; Soto and Alvarado 2006). Since initiation, Arenal volcano appears to have gone through several eruptive cycles that have started with plinian eruptions that also represent the most silicic magmas (Borgia et al. 1988; Soto and Alvarado 2006). Over the course of its eruptive history, Arenal had plinian, subplinian, vulcanian and strombolian eruptions, and lava flow fields developed throughout activity phases (Soto and Alvarado 2006). Similarly, explosive activity of the recent eruption varied. The initiation in July, 1968 was marked by a few plinian eruptions and followed later on by a combination of strombolian activity and lava flows until 1984 (Malavassi et al. 1998; Melson et al. 1999), then Arenal began a more explosive stage characterized by frequent small-scale vulcanian-strombolian explosions and rare pyroclastic flows (Malavassi et al. 1998). Lava flows erupted intermittently over the entire 1968-2010 eruption. Therefore, it appears that the recent eruption covered most eruption styles and is likely representative of what explosive and effusive activities through most of Arenal lifecycle has looked like. The only eruptions that are missing are eruptions producing basaltic/dacitic tephras that occurred only a few times and are volumetrically minor. All lava compositions are crystal-rich (161 to $\sim 50 \%$, Fig. 1a-c) except for crystal-poor andesitic/dacitic tephra (Bolge et al. 2006).

Petrographically, the bulk of Arenal magmas are plagioclase-rich, two-pyroxene basaltic andesites with one FeTi-oxide and occasionally olivine (Fig. 1) (e.g., Reagan et al. 1987; Streck et al. 2005; Bolge et al. 2006). Hornblende occurs sporadically in a few stratigraphic positions like in material from the initial phase of the recent eruption (Fig. 1d) (Reagan et al. 1987; Borgia et al. 1988), which was taken as indication for the beginning of each eruptive phase to be marked by high $\mathrm{H}_{2} \mathrm{O}$ content in the melt, which decreases over the course of the cycle (Borgia et al. 1988). Contrary to the overall petrographic similarity and compositional homogeneity of basaltic andesites, detailed investigations of mineral and melt inclusion compositions reveal a high degree of complexity. Based on the range of mineral compositions in combination with mutual mineral inclusions, Streck et al. (2005) distinguished distinct crystallization environments reflecting different physical conditions during crystal growth and changes in the melt composition.

Pre-eruptive conditions of Arenal magmas: results of geothermobarometry and previous experimental studies

There are few constraints on the pre-eruptive conditions of Arenal magmas. Most of the data that do exist are on rocks from the just recently terminated 1968-2010 eruptions, which has transitioned into a fumarolic stage. Thermometry from pyroxene and oxide compositions suggest a temperature of $1,000-1,100{ }^{\circ} \mathrm{C}$ and oxidized conditions around $\mathrm{NNO}+1$, where NNO is nickel-nickel oxide buffer (expressed as $\Delta \log f \mathrm{O}_{2}$ ) (Cigolini 1998). The high $\mathrm{fO}_{2}$ (NNO +1.3 ) of gabbroic xenoliths and the early saturation of magmas in titanomagnetite (Reagan et al. 1987) plus the fractionation assemblage of plagioclase (An89), 

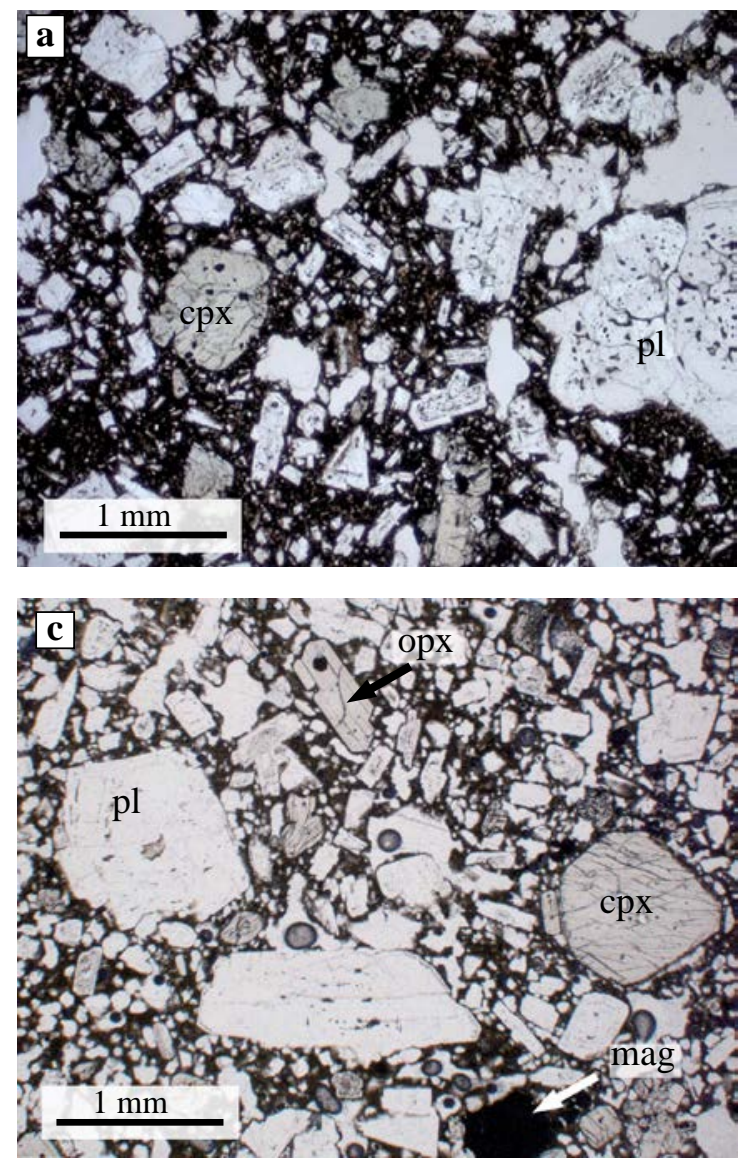

Fig. 1 Microphotographs of crystal-poor and crystal-rich basalt and basaltic andesite tephras from Arenal volcano. a Ar7/71 (35 vol\% crystal, 55 wt $\% \mathrm{SiO}_{2}$ ); b Ar7/68 (7 vol\% crystal, 56 wt\% $\mathrm{SiO}_{2}$ ); c

orthopyroxene, clinopyroxene and magnetite (Ryder et al. 2006) suggest that Arenal magmas have relatively high oxygen fugacity. The absence of hornblende in lavas erupting between 1968 and 1970-1974 (Reagan et al. 1987) could be interpreted solely as a result of lower volatile content, which in turn could have led to the change of the eruption style with time at Arenal volcano (from highly explosive to more effusive). However, the persistence of An-rich plagioclase $\left(\mathrm{An}_{85-92}\right)$ throughout the 1968-2010 eruption (Streck et al. 2005) associated with water-rich melt inclusions (up to $4 \mathrm{wt} \% \mathrm{H}_{2} \mathrm{O}$, Wade et al. (2006) and $>5 \mathrm{wt} \%$ $\mathrm{H}_{2} \mathrm{O}$, Streck and Wacaster (2006)) suggests that water-rich magmas persisted even if hornblende was not present in the mineral assemblage. The observed continuous degassing at Arenal volcano in combination with water-rich magmas indicates that fluid-saturated conditions and degassing were occurring at depth. Wade et al. (2006) estimated up to $4 \mathrm{wt} \% \mathrm{H}_{2} \mathrm{O}$ and $300 \mathrm{ppm} \mathrm{CO}_{2}$ in basaltic melt inclusions in olivine (ET6 and ET3). Using mixed $\mathrm{H}_{2} \mathrm{O}-\mathrm{CO}_{2}$ vaporsaturation isobars for basaltic compositions typical for arc magmatism (Shishkina et al. 2010; Iacono-Marziano et al.
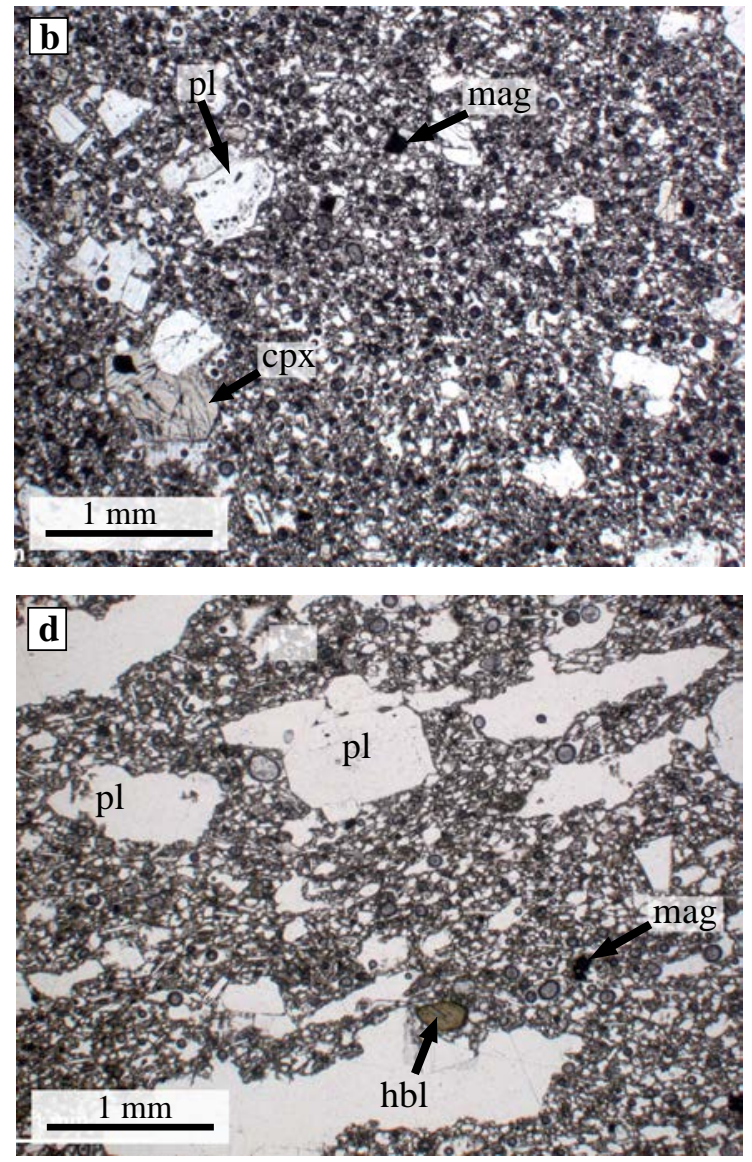

ET3-1 (15 vol\% crystal, 50.5 wt\% $\mathrm{SiO}_{2}$ ); d ET3-2 (7 vol\% crystal, $55 \mathrm{wt} \% \mathrm{SiO}_{2}$ ). cpx clinopyroxene, mag magnetite, opx orthopyroxene, $p l$ plagioclase

2012), inclusions with the highest $\mathrm{H}_{2} \mathrm{O}$ contents from Arenal were trapped at $\sim 200 \mathrm{MPa}$ indicating that $\sim 7 \mathrm{~km}$ was the minimum depth at which fluid saturation was attained.

Few experimental studies have been performed to shed light on the different processes at upper crustal depths beneath Arenal volcano. Szramek et al. (2006) performed water-saturated crystallization and decompression experiments at NNO and examined groundmass textures to constrain the ascent rate of magmas produced from explosive and effusive eruptions (tephras and lavas, respectively). Based on the phase assemblage of plagioclase $\mathrm{An}_{80}$, clinopyroxene, orthopyroxene and magnetite, they suggest that Arenal magmas last equilibrated at $940-1,000{ }^{\circ} \mathrm{C}$ and 50 $145 \mathrm{MPa}$, assuming a water-saturated system. For relatively An-rich plagioclase $\left(\mathrm{An}_{86-89}\right)$ to coexist with pyroxenes, a temperature less than $1,000{ }^{\circ} \mathrm{C}$ is needed at $P \sim 200 \mathrm{MPa}$ (Szramek et al. 2006). Petermann and Lundstrom (2006) conducted water-undersaturated phase equilibria experiments using a basaltic andesitic bulk composition erupted in 1971 (AR8, Reagan et al. 1987) and reported that plagioclase $\mathrm{An}_{67}$ and $\mathrm{An}_{83}$ were present in run products obtained 
Table 1 Composition of natural samples and starting material (glass)

Bulk rock composition from $\mathrm{XRF}$ analysis performed at the Universities of Geneva ${ }^{\mathrm{a}}$ and Washington ${ }^{\mathrm{b}}$. Glass composition from microprobe analysis, University of Montpellier. $n$, number of microprobe analyses; bracketed number, $\mathrm{X}$-ray counting error and range of determined values; $\mathrm{Mg} \#=\mathrm{Mg}+\mathrm{Fet}^{*} 100$, molar

\begin{tabular}{|c|c|c|c|c|c|c|c|}
\hline \multirow[t]{2}{*}{$\mathrm{wt} \%$} & \multirow{2}{*}{$\begin{array}{l}\text { Ar7/68 } \\
\text { Bulk rock }^{\mathrm{a}}\end{array}$} & \multirow{2}{*}{$\begin{array}{l}\text { ET3-1 } \\
\text { Bulk rock }^{\mathrm{a}}\end{array}$} & \multirow{2}{*}{$\begin{array}{l}\text { ET3-2 } \\
\text { Bulk rock }^{\mathrm{a}}\end{array}$} & \multirow{2}{*}{$\begin{array}{l}\text { ET2 } \\
\text { Bulk rock }^{\mathrm{a}}\end{array}$} & \multirow{2}{*}{$\begin{array}{l}\text { MJS05-SCPN } \\
\text { Bulk rock }^{b}\end{array}$} & \multicolumn{2}{|c|}{ MJS05-SCPN } \\
\hline & & & & & & $\overline{\text { Glass }}$ & $n=5$ \\
\hline $\mathrm{SiO}_{2}$ & 55.99 & 50.56 & 54.90 & 61.55 & 50.76 & 50.70 & $(0.40)$ \\
\hline $\mathrm{TiO}_{2}$ & 0.57 & 0.63 & 0.57 & 0.75 & 0.84 & 0.82 & $(0.02)$ \\
\hline $\mathrm{Al}_{2} \mathrm{O}_{3}$ & 20.30 & 20.83 & 20.44 & 16.70 & 18.52 & 18.47 & $(0.17)$ \\
\hline $\mathrm{FeO}^{\mathrm{a}}$ & 6.95 & 9.16 & 8.03 & 6.63 & 9.31 & 9.20 & $(0.16)$ \\
\hline $\mathrm{MnO}$ & 0.15 & 0.16 & 0.17 & 0.08 & 0.19 & 0.18 & $(0.04)$ \\
\hline $\mathrm{MgO}$ & 2.96 & 5.13 & 3.02 & 1.99 & 5.95 & 5.98 & $(0.05)$ \\
\hline $\mathrm{CaO}$ & 8.77 & 10.69 & 8.92 & 5.30 & 10.84 & 10.90 & $(0.11)$ \\
\hline $\mathrm{Na}_{2} \mathrm{O}$ & 3.41 & 2.28 & 3.13 & 3.98 & 2.72 & 2.70 & $(0.01)$ \\
\hline $\mathrm{K}_{2} \mathrm{O}$ & 0.70 & 0.41 & 0.63 & 2.53 & 0.63 & 0.65 & $(0.05)$ \\
\hline $\mathrm{P}_{2} \mathrm{O}_{5}$ & 0.19 & 0.16 & 0.20 & 0.22 & 0.24 & 0.22 & $(0.02)$ \\
\hline Total & 99.99 & 100.00 & 100.00 & 99.74 & 100.00 & 99.82 & $(0.50)$ \\
\hline Mg\# & 43.0 & 49.8 & 40.0 & 34.8 & 53.1 & 53.6 & \\
\hline
\end{tabular}

at $1,200{ }^{\circ} \mathrm{C}$ and $500 \mathrm{MPa}$ for melt water contents $\left(\mathrm{H}_{2} \mathrm{O}_{\text {melt }}\right)$ of 0.5 and $2 \mathrm{wt} \% \mathrm{H}_{2} \mathrm{O}$, respectively. Given the much lower An contents of plagioclase in their experiments in comparison to what is observed, Petermann and Lundstrom (2006) suggested that Arenal magma last equilibrated at 940-1,150 ${ }^{\circ} \mathrm{C}$ and $\mathrm{H}_{2} \mathrm{O}_{\text {melt }}>2 \mathrm{wt} \%$. Hence, the previous experiments did not constrain the magma storage conditions prior to the eruption (50-500 $\mathrm{MPa}$ ) and failed to reproduce hornblende and plagioclase with very high An contents observed in the natural products (Petermann and Lundstrom 2006; Szramek et al. 2006).

By taking the available information on thermometric and experimental studies into account, we investigated the phase relationships of Arenal magmas at $200 \mathrm{MPa}$ (e.g., minimum trapping pressure of melt inclusion), oxidizing conditions and various fluid compositions and performed crystallization experiments aimed at reproducing observed phase assemblages and compositions. The results are used to better constrain magma storage conditions below Arenal during the 1968-2010 eruption but also to understand compositional trends of all Arenal magmas since inception.

\section{Experimental approach}

Starting material and experimental rational

The starting material selected for the experiments is the most mafic and crystal-poor Arenal-type basalt that we are aware of. This sample (MJS05-SCPN, Table 1) comes from a scoria cone $30 \mathrm{~km}$ west of Arenal volcano. The natural rock contains only $3 \%$ phenocrysts consisting of olivine $\left(\mathrm{Fo}_{92}\right)$, clinopyroxene $(\mathrm{Mg} \#=82)$, orthopyroxene $(\mathrm{Mg \#}=80)$, plagioclase $\left(\mathrm{An}_{86}\right)$ and magnetite $\left(\mathrm{X}_{\text {ulvö }}=0.13\right)$ in approximate following percentages
50/25/10/10/5 (Table 2; Fig. 2). The eruption of basalt from Arenal itself is rare. Over its 7,000 year long activity period, basalt is found only at three stratigraphic levels (Borgia et al. 1988). MJS05-SCPN belongs to the lower $\mathrm{Al}$ group of basalts reported by Borgia et al. (1988) and is significantly more primitive than any data reported from Arenal (Table 1) (Borgia et al. 1988; Bolge et al. 2006). For example, the highest concentrations in $\mathrm{Cr}$ and $\mathrm{Ni}$ of basaltic magmas from Arenal are 80 and 45 ppm, respectively, while our starting sample contains 187 and 79 ppm (cf. Bolge et al. 2006). We placed priority on using a nearly aphyric basalt sample as we wanted to ensure that the starting material represents a melt composition uncompromised by the possible addition of phenocrysts (cf. Streck et al. 2005). Basaltic magmas erupted directly from Arenal contain 16 to $>30 \%$ phenocrysts (Bolge et al. 2006).

\section{Experimental charge}

Crystallization experiments were conducted using a dry glass as starting material. This glass was prepared by fusing $10 \mathrm{~g}$ of the crushed basaltic tephra (MJS05-SCPN) in a Pt crucible at $1,400{ }^{\circ} \mathrm{C}$ and $1 \mathrm{~atm}$. for $3 \mathrm{~h}$. After fusing, the glass was crushed and fused again at the same conditions to avoid heterogeneity. The resulting glass was finely crushed in an agate mortar (grain size $<200 \mu \mathrm{m}$ ). Electron microprobe analyses showed that this glass is homogeneous within analytical uncertainty and that $\mathrm{Fe}$ and $\mathrm{Na}$ losses during fusion were minimal (compare XRF analysis of natural sample with microprobe analysis of dry glass; Table 1).

Charges were loaded into $\mathrm{Au}$ capsules (15 mm length, $2.8 \mathrm{~mm}$ internal diameter and $0.2 \mathrm{~mm}$ wall thickness). First, water as pure $\mathrm{H}_{2} \mathrm{O}$ and then $\mathrm{CO}_{2}$ as silver oxalate $\left(\mathrm{Ag}_{2} \mathrm{C}_{2} \mathrm{O}_{4}\right.$ which decomposes to $\mathrm{Ag}$ and $\mathrm{CO}_{2}$ at low 
Table 2 Experimental conditions and mineral assemblage

\begin{tabular}{|c|c|c|c|c|c|c|}
\hline & $\mathrm{T}^{\circ} \mathrm{C}$ & $X \mathrm{H}_{2} \mathrm{O}_{\text {in }}$ & $\log f \mathrm{O}_{2}$ & $\triangle \mathrm{NNO}$ & $\mathrm{H}_{2} \mathrm{O}_{\text {melt }}$ & Phase proportions (vol\%) \\
\hline \multicolumn{7}{|l|}{ Starting material } \\
\hline MJS05-SCPN & & & & & & $\mathrm{ol}(1.5), \operatorname{cpx}(0.7), \mathrm{opx}(0.3), \mathrm{pl}(0.3), \operatorname{mag}(0.2)$ \\
\hline \multicolumn{7}{|c|}{ Experimental runs $-P=200 \mathrm{MPa}$} \\
\hline MJS05 \#1 & 1,050 & 1.00 & -6.93 & 2.55 & 4.98 & mag (3) \\
\hline MJS05 \#3 & 1,050 & 0.87 & -7.05 & 2.43 & 4.38 & $\operatorname{mag}(3)$ \\
\hline MJS05 \#2 & 1,050 & 0.85 & -7.14 & 2.35 & 4.39 & $\operatorname{cpx}(3), \operatorname{mag}(2)$ \\
\hline MJS05 \#4 & 1,050 & 0.55 & -7.46 & 2.02 & 3.16 & $\operatorname{cpx}(7), \mathrm{ol}(2), \operatorname{mag}(2)$ \\
\hline MJS05 \#5 & 1,050 & 0.35 & -7.85 & 1.63 & 2.54 & $\operatorname{cpx}(9), \operatorname{opx}(2), \operatorname{mag}(4)$ \\
\hline MJS05 \#6 & 1,000 & 1.00 & -7.67 & 2.55 & 6.25 & ol(2), $\operatorname{cpx}(9), \operatorname{pl}(10), \operatorname{mag}(2)$ \\
\hline MJS05 \#7 & 1,000 & 0.86 & -7.80 & 2.43 & 5.20 & $\mathrm{ol}(5), \operatorname{cpx}(9), \operatorname{pl}(20), \operatorname{mag}(4)$ \\
\hline MJS05 \#8 & 1,000 & 0.76 & -7.91 & 2.32 & 5.43 & $\operatorname{cpx}(9)$, opx(4), pl(22), mag(6) \\
\hline MJS05 \#9 & 1,000 & 0.54 & -8.21 & 2.01 & n.d. & cpx, opx, pl, mag \\
\hline MJS05 \#10 & 1,000 & 0.36 & -8.56 & 1.66 & n.d. & cpx, opx, pl, mag \\
\hline MJS05 \#11 & 950 & 1.00 & -8.47 & 2.55 & 6.11 & $\operatorname{cpx}(13), \operatorname{pl}(25), \operatorname{hbl}(5), \operatorname{mag}(2)$ \\
\hline MJS05 \#12 & 950 & 0.87 & -8.60 & 2.43 & n.d. & cpx, opx, pl, hbl, mag \\
\hline MJS05 \#13 & 950 & 0.76 & -8.71 & 2.31 & n.d. & cpx, opx, pl, mag \\
\hline MJS05 \#14 & 950 & 0.57 & -8.96 & 2.06 & n.d. & cpx, opx, pl, mag \\
\hline MJS05 \#15 & 950 & 0.34 & -9.40 & 1.63 & n.d. & $c p x, o p x, p l$, mag \\
\hline MJS05 \#16 & 900 & 1.00 & -9.34 & 2.55 & n.d. & cpx, pl, hbl, mag, ap \\
\hline MJS05 \#17 & 900 & 0.87 & -9.46 & 2.43 & n.d. & cpx, opx, pl, hbl, mag, ap \\
\hline MJS05 \#18 & 900 & 0.76 & -9.58 & 2.31 & n.d. & cpx, opx, pl, mag \\
\hline MJS05 \#19 & 900 & 0.54 & -9.88 & 2.02 & n.d. & $c p x, o p x, p l$, mag \\
\hline MJS05 \#20 & 900 & 0.39 & -10.16 & 1.73 & n.d. & $c p x, o p x, p l$, mag \\
\hline
\end{tabular}

$\mathrm{XH}_{2} \mathrm{O}_{\text {in }}$ : initial fluid composition $\left(\mathrm{H}_{2} \mathrm{O} /\left(\mathrm{H}_{2} \mathrm{O}+\mathrm{CO}_{2}\right)\right.$ : molar), NNO: is nickel-nickel oxide buffer (expressed as $\left.\Delta \log f \mathrm{O}_{2}\right)$, n.d.: not determined, volume \% estimated using image analyses of whole thin section, in italic: crystal expected, cpx: clinopyroxene, opx: orthopyroxene, ol: olivine, hbl: hornblende, pl: plagioclase, mag: magnetite, ap: apatite

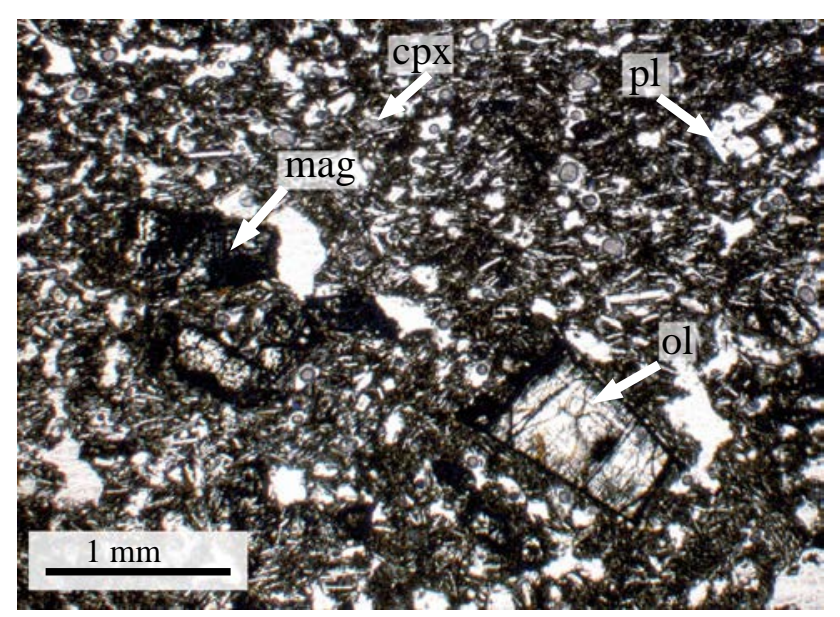

Fig. 2 Microphotograph of crystal-poor basalt (MJSO5-SCPN, starting material)

temperature) were loaded into the capsule. The rock powder was added in a second stage. All experiments are fluid saturated, and the weight proportion of fluid components $\mathrm{H}_{2} \mathrm{O}+\mathrm{CO}_{2}\left[\left(\mathrm{H}_{2} \mathrm{O}+\mathrm{CO}_{2}\right) /\left(\mathrm{H}_{2} \mathrm{O}+\mathrm{CO}_{2}+\right.\right.$ silicate $)$, in wt\%] was fixed to be around 0.1 in all experiments. The initial fluid phase composition $X \mathrm{H}_{2} \mathrm{O}_{\text {in }}\left(X_{2} \mathrm{H}_{2} \mathrm{O}_{\text {in }}=\mathrm{H}_{2} \mathrm{O} /\right.$ $\left(\mathrm{H}_{2} \mathrm{O}+\mathrm{CO}_{2}\right)$, molar) varied between 0.33 and 1 . Upon loading, the capsules were sealed by arc welding. After welding and after completion of the experiments, the capsules were weighted again to ensure that there had been no loss of water and $\mathrm{CO}_{2}$ at high pressure and temperature. To evaluate the extent of iron loss to the sample containers during the experiments, the gold capsules were analyzed by electron microprobe. Results showed that iron loss is small $(<0.1 \mathrm{wt} \% \mathrm{FeO})$.

\section{Experimental procedure}

The crystallization experiments were carried out in an internally heated pressure vessel at the University of Hanover (IHPV, described in Berndt et al. (2002)) at $200 \mathrm{MPa}$ and $900-1,050{ }^{\circ} \mathrm{C}$. Pressure was monitored by a strain gauge manometer and it varied by $<5 \mathrm{MPa}$ during the experiments. Four thermocouples were used to control the temperature gradient along the capsule length. In all experiments, the thermal gradient was $\pm 3{ }^{\circ} \mathrm{C}$. 
The run duration was $96 \mathrm{~h}$ which is sufficient to attain near-equilibrium conditions with basaltic compositions in the investigated temperature range (e.g., Freise et al. 2009). The IHPVs were pressurized with pure Ar gas, and all experiments were performed at the intrinsic redox conditions of the vessels $\left(\log f \mathrm{O}_{2}=\mathrm{NNO}+2.5\right.$; Schuessler et al. 2008). To avoid crystallization of quench crystal from the melt, quenching was accomplished isobarically by dropping down the capsules into the cold part of the vessel. The sample is fixed to a Pt-wire in the hot spot of the furnace and is quenched by fusing the Pt-wire electrically. The cooling rates are estimated around $150{ }^{\circ} \mathrm{C}$ per second (Berndt et al. 2002).

In the IHPV pressurized with Ar gas, the oxygen fugacity within the capsule is related to the fugacity of water and hydrogen through the equilibrium reaction $\mathrm{H}_{2}+1 / 2 \mathrm{O}_{2} \leftrightarrow$ $\mathrm{H}_{2} \mathrm{O}$. At the investigated temperatures and pressure, the oxygen fugacity in the capsules with $\mathrm{H}_{2} \mathrm{O}$-saturated melts $\left(\mathrm{CO}_{2}\right.$-free $)$ is close to $\mathrm{NNO}+2.5$. However, in experiments with mixed $\mathrm{CO}_{2}-\mathrm{H}_{2} \mathrm{O}$-bearing fluids (water-undersaturated), the $\mathrm{fO}_{2}$ is lower and can be estimated using the relation: $\log f \mathrm{O}_{2}=\log f \mathrm{O}_{2}\left(\right.$ at $\left.X \mathrm{H}_{2} \mathrm{O}_{\text {in }}=1\right)+2 \log X \mathrm{H}_{2} \mathrm{O}_{\text {fluid }}$ [see for example detailed discussion in Botcharnikov et al. (2005) and Schuessler et al. (2008)]. The difference of fluid phase composition before and after experiments, $\mathrm{XH}_{2} \mathrm{O}_{\text {in }}$ and $\mathrm{XH}_{2} \mathrm{O}_{\text {fluid }}$, respectively, due to the higher solubility of water in the melt when compared to the solubility of $\mathrm{CO}_{2}$ implies that $X \mathrm{H}_{2} \mathrm{O}_{\text {fluid }}$ is always lower than $X \mathrm{H}_{2} \mathrm{O}_{\text {in }}$. At near liquidus conditions, the difference $X \mathrm{H}_{2} \mathrm{O}_{\text {in }}-X_{2} \mathrm{O}_{\text {fluid }}$ is expected to be the highest and mass balance calculations show that this value is in the range $0.2-0.3$ for intermediate $\mathrm{XH}_{2} \mathrm{O}_{\text {in }}(0.4-0.6)$. Based on the formulation given above, this implies that the $\mathrm{fO}_{2}$ values given in Table 2 may be lower by up to $0.2-0.4 \mathrm{log}$ units, depending on the amount of crystal in the run products and on the $\mathrm{XH}_{2} \mathrm{O}_{\text {in }}$ (Whitney 1972; Webster et al. 1987; Botcharnikov et al. 2005; Schuessler et al. 2008).

\section{Analytical methods}

Mineral and glass compositions were determined at Geosciences Montpellier using a Cameca SX100 electron microprobes fitted with a WDS system at operating conditions of $15 \mathrm{kV}$ and $10 \mathrm{nA}$. To minimize $\mathrm{Na}$ loss, $\mathrm{Na}$ was counted first and a defocused beam (10-20 $\mu \mathrm{m})$ was used to analyze glass. Mineral analyses were done in spot mode $(1-2 \mu \mathrm{m})$. All elements were analyzed for $10 \mathrm{~s}$. Standards used for calibration were $\mathrm{Fe}_{2} \mathrm{O}_{3}, \mathrm{MgO}, \mathrm{MnTiO}_{3}(\mathrm{Mn}$ and $\mathrm{Ti}$ ), $\mathrm{Al}_{2} \mathrm{O}_{3}(\mathrm{Al})$, albite $(\mathrm{Na})$, wollastonite ( $\mathrm{Si}$ and $\mathrm{Ca}$ ), apatite $(\mathrm{P})$ and orthoclase $(\mathrm{K})$. The standard deviations (2-18 analysis points) given in the data tables for mineral and glass analyses correspond to one standard deviation of replicate analyses. Due to the small size of the crystals
$(<5 \mu \mathrm{m})$ and the small amount of glass in experiments performed at low $\mathrm{XH}_{2} \mathrm{O}_{\text {in }}$, it was not possible to obtain accurate analyses of the composition of minerals and glass (in such cases, the analyses are not reported in the tables and figures). However, phases could be qualitatively identified [by energy-dispersive spectrometry (EDS) + microprobe] and the characterization of the stability field of individual minerals was possible (Table 2).

The water content of the experimental glasses was determined using a series of volatile-bearing glass standards with andesitic and rhyolitic composition and different water contents $\left(0.1-8 \mathrm{wt} \% \mathrm{H}_{2} \mathrm{O}\right)$ measured by Karl Fischer Titration analyses, following the "by-difference" method described in Devine et al. (1995) and Koepke (1997). Glass standards were analyzed during each electron microprobe session, and the obtained calibration curve was used to improve the analyses of the water content. Using this technique, the uncertainty is in the range \pm 0.5 to $0.7 \mathrm{wt} \% \mathrm{H}_{2} \mathrm{O}$.

\section{Results}

Phase equilibria and modal abundances

The phase stability fields for the basaltic composition have been determined at $200 \mathrm{MPa}$ in the temperature range 900$1,050{ }^{\circ} \mathrm{C}$ and for $3-6 \mathrm{wt} \% \mathrm{H}_{2} \mathrm{O}_{\text {melt }}$. Experimental run products show homogeneous distribution of all phases (glass, crystals and bubbles), homogeneity of crystal and bubble sizes and euhedral crystal shapes (Fig. 3). The mineral assemblages vary as a function of temperature and initial fluid phase composition $\left(\mathrm{XH}_{2} \mathrm{O}_{\text {in }}\right)$ and $\mathrm{H}_{2} \mathrm{O}_{\text {melt }}$ (Figs. 3, 4; Table 2). At $1,050{ }^{\circ} \mathrm{C}$ and water-saturated conditions $\left(\mathrm{H}_{2} \mathrm{O}_{\text {melt }} \sim 5-6 \mathrm{wt} \%\right)$, only magnetite is present. Magnetite + clinopyroxene and magnetite + clinopyroxene + olivine crystallize with decreasing water activity (Figs. 3, 4). Plagioclase and clinopyroxene crystallize at water-saturated conditions with olivine at $1,000{ }^{\circ} \mathrm{C}$ and with amphibole at 950-900 ${ }^{\circ} \mathrm{C}$, whereas they crystallize with orthopyroxene at low water content (for $\mathrm{T}=1,000-900{ }^{\circ} \mathrm{C}$ ). Olivine is stable over a very small range of temperature $\left(\Delta \mathrm{T}=50^{\circ} \mathrm{C}\right)$. Orthopyroxene has not been found with olivine and crystallizes in water-undersaturated experiments. With increasing water activity $\left(\mathrm{XH}_{2} \mathrm{O}_{\text {in }}=0.8-1\right)$, amphibole is stable. Amphibole, plagioclase and pyroxenes are stable together at $\mathrm{T}=950-900{ }^{\circ} \mathrm{C}$ and $\mathrm{H}_{2} \mathrm{O}_{\text {melt }}=5-6 \mathrm{wt} \%$. For relatively low water content $\left(\mathrm{H}_{2} \mathrm{O}_{\text {melt }}<4 \mathrm{wt} \%\right)$, amphibole is not present and clinopyroxene and orthopyroxene are stable phases. Plagioclase crystallizes in all experimental runs at $\mathrm{T}<1,050{ }^{\circ} \mathrm{C}\left(2.5-6 \mathrm{wt} \% \mathrm{H}_{2} \mathrm{O}_{\text {melt }}\right)$.

Apatite has been observed only in charges at $900{ }^{\circ} \mathrm{C}$ and $X \mathrm{H}_{2} \mathrm{O}_{\text {in }}=0.87-1$. Apatite has not been detected in products with high crystal contents (low temperature or low $\mathrm{H}_{2} \mathrm{O}_{\text {melt }}$; 

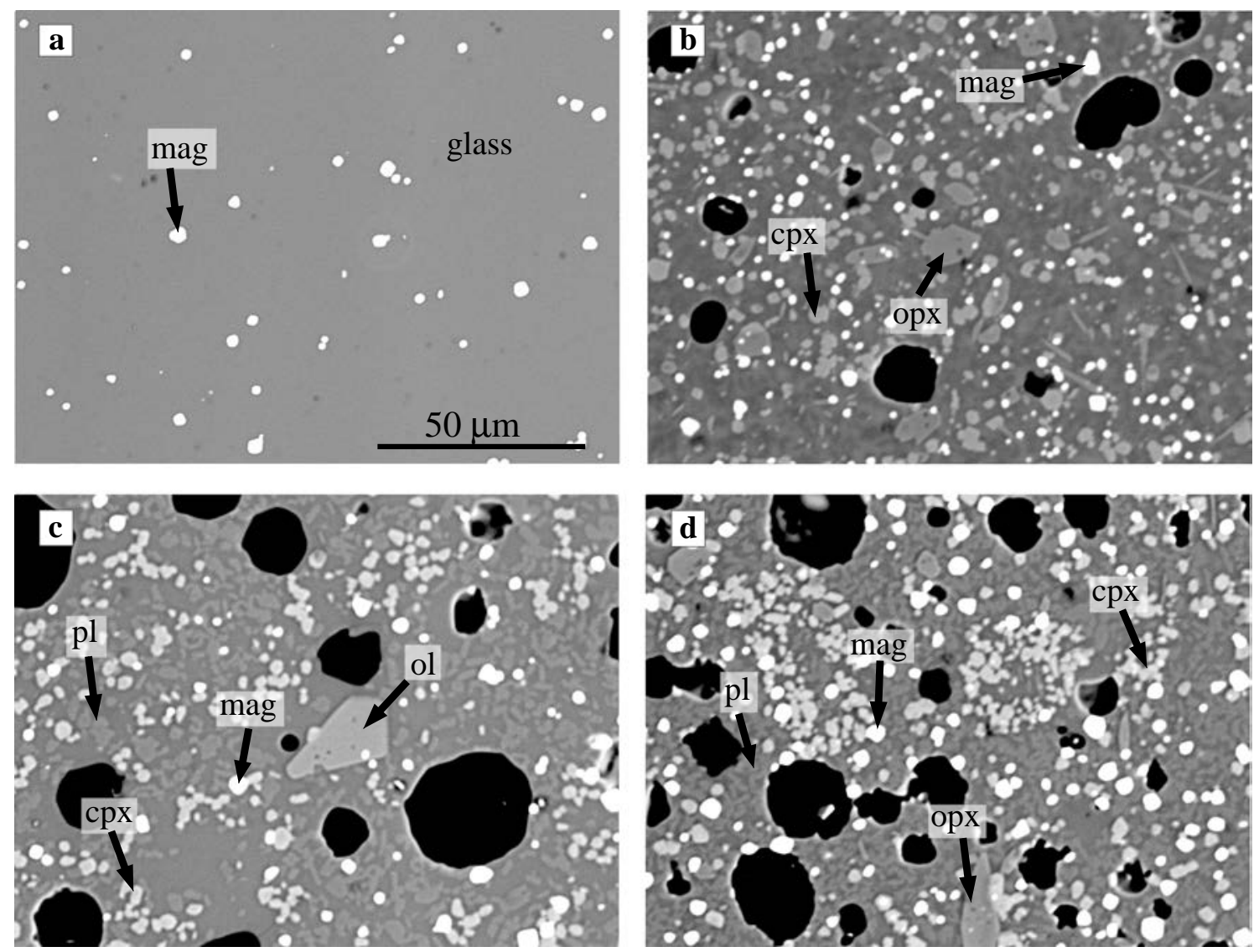

Fig. 3 Backscattered electron images of run products. a Run \#1, $1,050{ }^{\circ} \mathrm{C}, X \mathrm{H}_{2} \mathrm{O}_{\text {in }}=1$; b Run \#5, $1,050{ }^{\circ} \mathrm{C}, X \mathrm{H}_{2} \mathrm{O}_{\text {in }}=0.6$; c Run \#7, $1,000{ }^{\circ} \mathrm{C}$, $X \mathrm{H}_{2} \mathrm{O}_{\text {in }}=0.9$; d Run \#8, $1,000{ }^{\circ} \mathrm{C}, X \mathrm{H}_{2} \mathrm{O}_{\text {in }}=0.7$. cpx clinopyroxene, mag magnetite, ol olivine, op $x$ orthopyroxene, $p l$ plagioclase

Table 2). However, at the same $\mathrm{T}$ but lower $\mathrm{H}_{2} \mathrm{O}_{\text {melt }}$, this mineral should be present and apatite may have formed very tiny phases, which could not be detected.

The proportions of phases identified in the experimental products were determined using image analysis (Table 2; Fig. 5). The modal abundance of crystal ranges from 3 vol\% at $1,050{ }^{\circ} \mathrm{C}$ to 40 vol\% at $950{ }^{\circ} \mathrm{C}$ and increases with decreasing $\mathrm{H}_{2} \mathrm{O}_{\text {melt }}$ as expected (e.g., at $950{ }^{\circ} \mathrm{C}$ : from 5 to $15 \mathrm{vol} \%$ for $\mathrm{H}_{2} \mathrm{O}=5-2.5 \mathrm{wt} \%$, respectively). At high temperature and at given $\mathrm{H}_{2} \mathrm{O}_{\text {melt }}$, we observe large variations of modal abundance of crystals ( $40 \mathrm{vol} \%$ crystals) for small variations of temperature $\left(1,050-1,000{ }^{\circ} \mathrm{C}\right)$.

Mineral and melt composition

The mineral composition varies as a function of temperature, initial fluid composition and oxygen fugacity (Table 3). The anorthite (An) content in plagioclase increases strongly with an increase in $\mathrm{H}_{2} \mathrm{O}_{\text {melt }}$ (up to $\mathrm{An}_{86}$ for $\mathrm{H}_{2} \mathrm{O}_{\text {melt }} \sim 5-6 \mathrm{wt} \%$ at $1,000{ }^{\circ} \mathrm{C}$ ) and temperature (e.g., from $\mathrm{An}_{72}$ to $\mathrm{An}_{86}$ for $\mathrm{T}=900$ to $1,000{ }^{\circ} \mathrm{C}$, respectively, at $\mathrm{XH}_{2} \mathrm{O}_{\text {in }}=1$ ) (Fig. 6; Table 3). The orthoclase content increases from $\mathrm{Or}_{0.5}$ to $\mathrm{Or}_{2}$ with a decrease in water content in the melt (Table 3).

Olivine composition varies from $\mathrm{Fo}_{80}$ to $\mathrm{Fo}_{85}$ at $\mathrm{T}=1,050{ }^{\circ} \mathrm{C}\left(\Delta \log f \mathrm{O}_{2}=\mathrm{NNO}+2\right)$ and $\mathrm{T}=1,000{ }^{\circ} \mathrm{C}$ $\left(\Delta \log f \mathrm{O}_{2}=\mathrm{NNO}+2.5\right)$, respectively (Fig. 7). Both augite and hypersthene are stable minerals over the range of experimental temperature $\left(900-1,050{ }^{\circ} \mathrm{C}\right)$. For augite, the wollastonite content (Wo) increases (Fig. 8), the ferrosilite (Fs) content decreases, and the enstatite (En) content is constant with an increase in oxygen fugacity and concomitant $\mathrm{H}_{2} \mathrm{O}_{\text {melt }}$ for a fixed temperature. In contrast, hypersthene shows an increase in En content and a decrease in Wo content with increasing $\mathrm{H}_{2} \mathrm{O}_{\text {melt }}$, whereas Fs content remains constant (Table 3). Mg-number increases with oxygen fugacity and temperature $(\mathrm{Mg} \#=74-81$ and $72-82$ for clinopyroxene and orthopyroxene, respectively, Fig. 8; Table 3). The $\mathrm{Al}_{2} \mathrm{O}_{3}$ content in clinopyroxene strongly decreases with decreasing $\mathrm{H}_{2} \mathrm{O}_{\text {melt }}$ (and increasing crystallinity) from $6 \mathrm{wt} \% \mathrm{Al}_{2} \mathrm{O}_{3}$ for $\mathrm{H}_{2} \mathrm{O}_{\text {melt }}=4.4 \mathrm{wt} \%$ to $4.2 \mathrm{wt} \% \mathrm{Al}_{2} \mathrm{O}_{3}$ for $\mathrm{H}_{2} \mathrm{O}_{\text {melt }}=2.5 \mathrm{wt} \%$ at $1,050{ }^{\circ} \mathrm{C}$ and from $5.5 \mathrm{wt} \% \mathrm{Al}_{2} \mathrm{O}_{3}$ for $\mathrm{H}_{2} \mathrm{O}_{\text {melt }}=6.3 \mathrm{wt} \%$ to $4.6 \mathrm{wt} \% \mathrm{Al}_{2} \mathrm{O}_{3}$ for $\mathrm{H}_{2} \mathrm{O}_{\text {melt }}=5.2 \mathrm{wt} \%$ at $1,000{ }^{\circ} \mathrm{C}$. $\mathrm{TiO}_{2}$ is constant $(0.7-0.8 \mathrm{wt} \%)$ in all experimental clinopyroxene. 

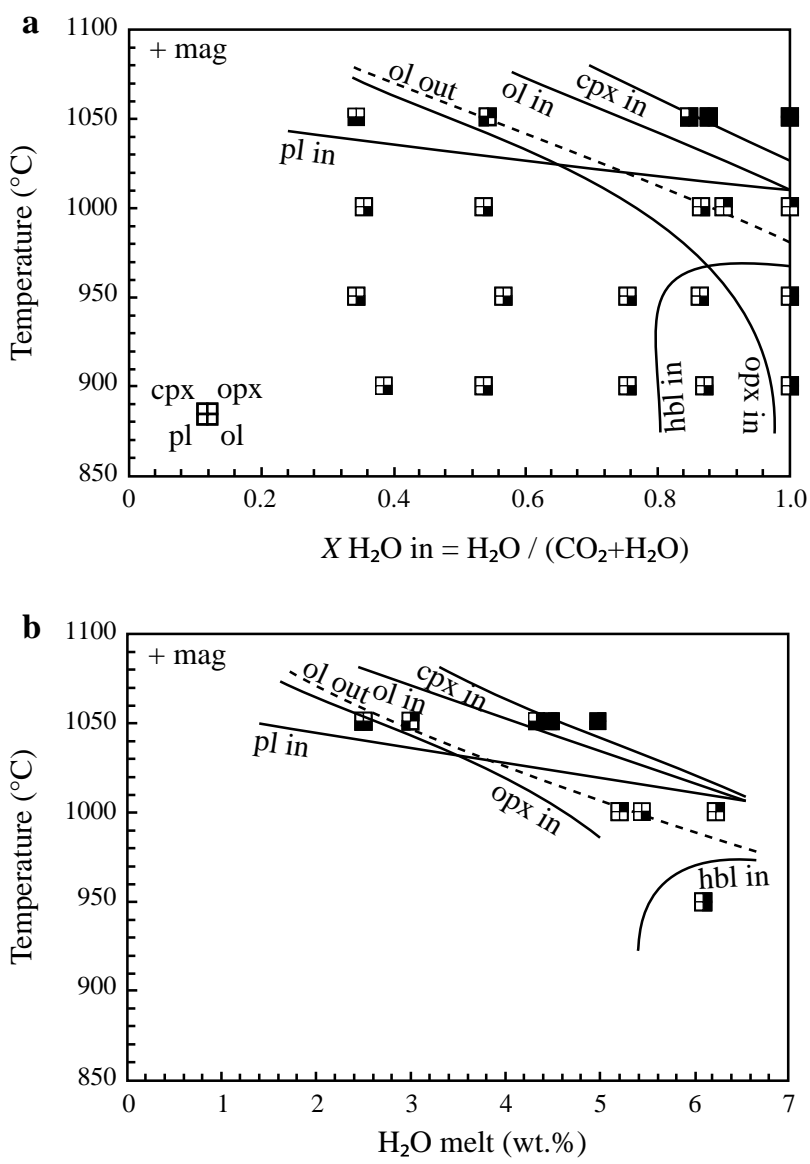

Fig. 4 Phase relations in experimental runs with basaltic andesite (MJS05-SCPN) as a function of temperature and a initial fluid composition $\left(\mathrm{XH}_{2} \mathrm{O}_{\text {in }}\right)$ and $\mathbf{b}$ water content in the glass at $200 \mathrm{MPa}$. Only experiments where analysis of melt was possible are reported in $\mathbf{b}$. cpx clinopyroxene, $h b l$ hornblende, mag magnetite, ol olivine, opx orthopyroxene, $p l$ plagioclase

Experimental amphiboles are euhedral unzoned calcic amphiboles (pargasitic and edentitic hornblende at 950 and $900{ }^{\circ} \mathrm{C}$, respectively, $(\mathrm{Ca}+\mathrm{Na})_{\mathrm{B}}>1 ; \mathrm{Na}_{\mathrm{B}}<0.5$; Leake et al. 1997) (Table 3). No significant variations in amphibole composition are observed as a function of temperature or $\mathrm{H}_{2} \mathrm{O}_{\text {melt }}$. Mg-number is in the range 74-76. The $\mathrm{SiO}_{2}$ content in amphibole increases and $\mathrm{Al}_{2} \mathrm{O}_{3}$ decreases with decreasing temperature.

The ulvöspinel component $\left(\mathrm{X}_{\text {ulvö }}\right)$ of magnetite decreases with increasing oxygen fugacity and temperature (Fig. 9; Table 3). The $\mathrm{MgO}$ and $\mathrm{Al}_{2} \mathrm{O}_{3}$ contents of magnetite increase with temperature, up to 7 and $8.8 \mathrm{wt} \%$ at $1,050{ }^{\circ} \mathrm{C}$, respectively.

The composition of the experimental melt ranges from basalt to andesite (52-60 $\mathrm{wt} \% \mathrm{SiO}_{2}$ ) and varies according to temperature and $\mathrm{H}_{2} \mathrm{O}_{\text {melt }}$. The evolution paths are similar at 1,000 and $1,050{ }^{\circ} \mathrm{C}$ (Fig. 10): $\mathrm{CaO}, \mathrm{MgO}$ and $\mathrm{FeO}$

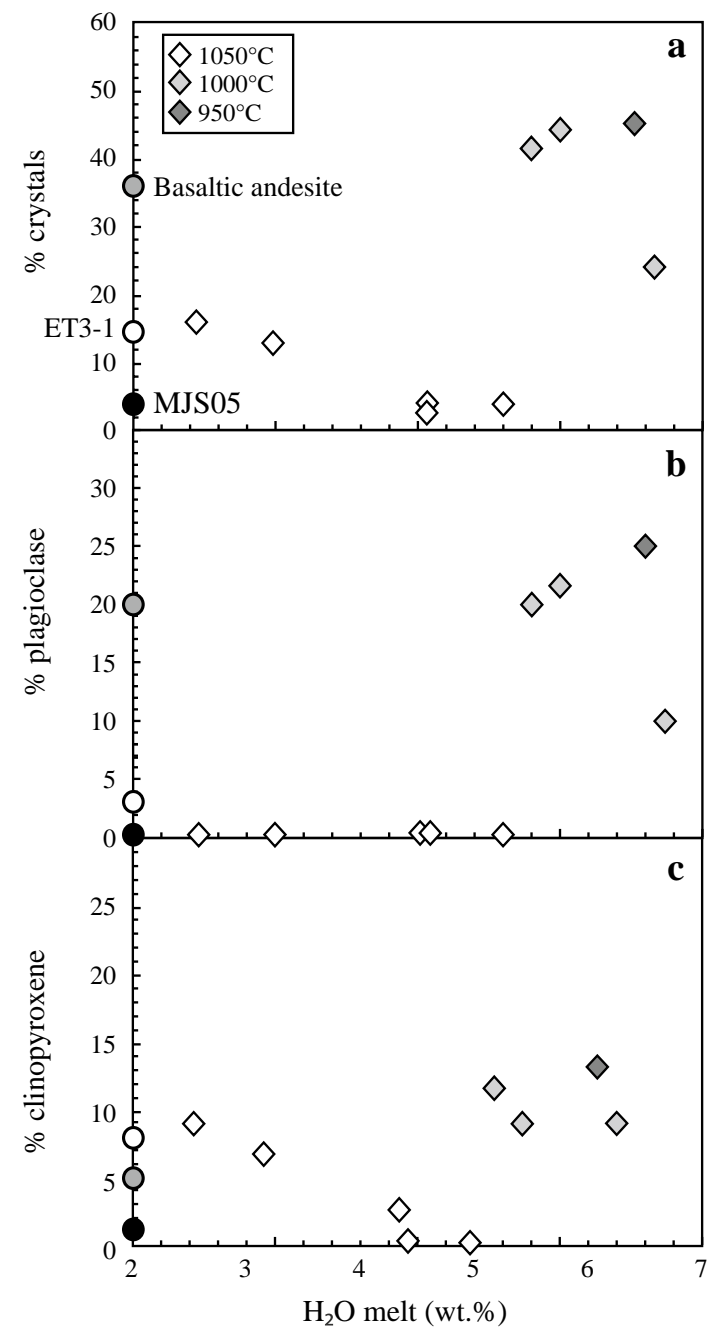

Fig. 5 Variation of modal abundances of a crystals, $\mathbf{b}$ plagioclase, and $\mathbf{c}$ clinopyroxene with water content in melt in experimental runs. Modal abundances of phenocrysts in natural basalt (ET3-1) and basaltic andesite from this study and Streck et al. (2005), respectively

contents decrease with a decrease in $\mathrm{H}_{2} \mathrm{O}_{\text {melt }}$ and temperature reflecting pyroxenes, olivine and oxides crystallization, whereas $\mathrm{K}_{2} \mathrm{O}$ and $\mathrm{Na}_{2} \mathrm{O}$ increases (a Na- and K-bearing phase is absent). $\mathrm{Al}_{2} \mathrm{O}_{3}$ is nearly constant and varies in the range 17.4-19 wt\% over the range of experimental temperatures. Changes in melt composition correlate with the observed changes in the phase proportions. The high $\mathrm{Al}_{2} \mathrm{O}_{3}$ concentrations reflect a low plagioclase proportion. $\mathrm{TiO}_{2}$ in the melt is constant as a function of temperature and is controlled by the amount of magnetite. The water solubility in $\mathrm{CO}_{2}$-free system (water-saturated) is up to 5 and $6 \mathrm{wt} \%$ in the silicate melt at 1,050 and $1,000{ }^{\circ} \mathrm{C}$, respectively. The water content in the melt decreases with decreasing $X_{2} \mathrm{H}_{2} \mathrm{O}_{\text {in }}$ (e.g., $\mathrm{H}_{2} \mathrm{O}_{\text {melt }}$ decreases from 5 to $2.5 \mathrm{wt} \%$ for $\mathrm{XH}_{2} \mathrm{O}_{\text {in }}=1$ to 0.35 at $1,050{ }^{\circ} \mathrm{C}$; Table 3 ). 


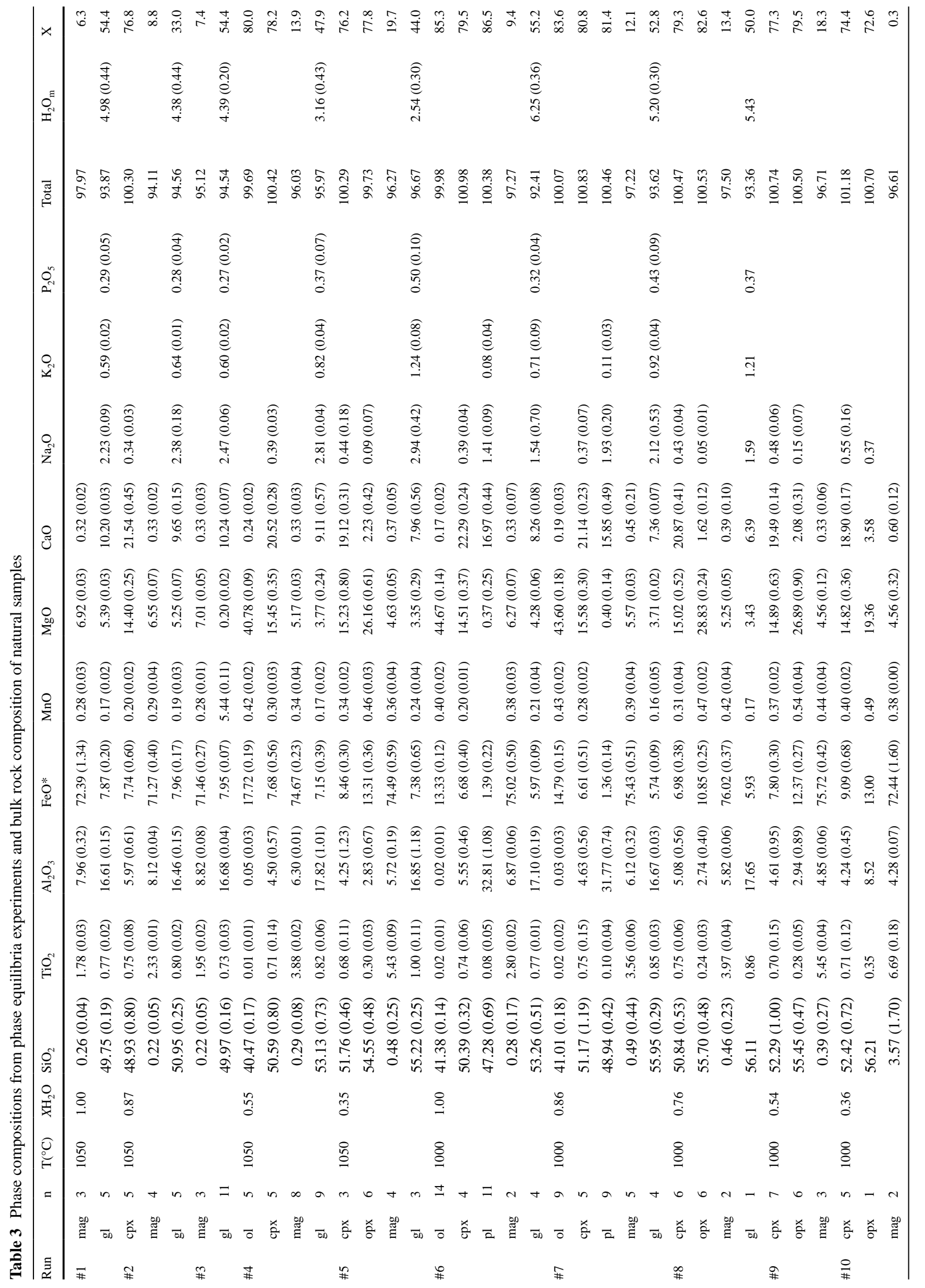




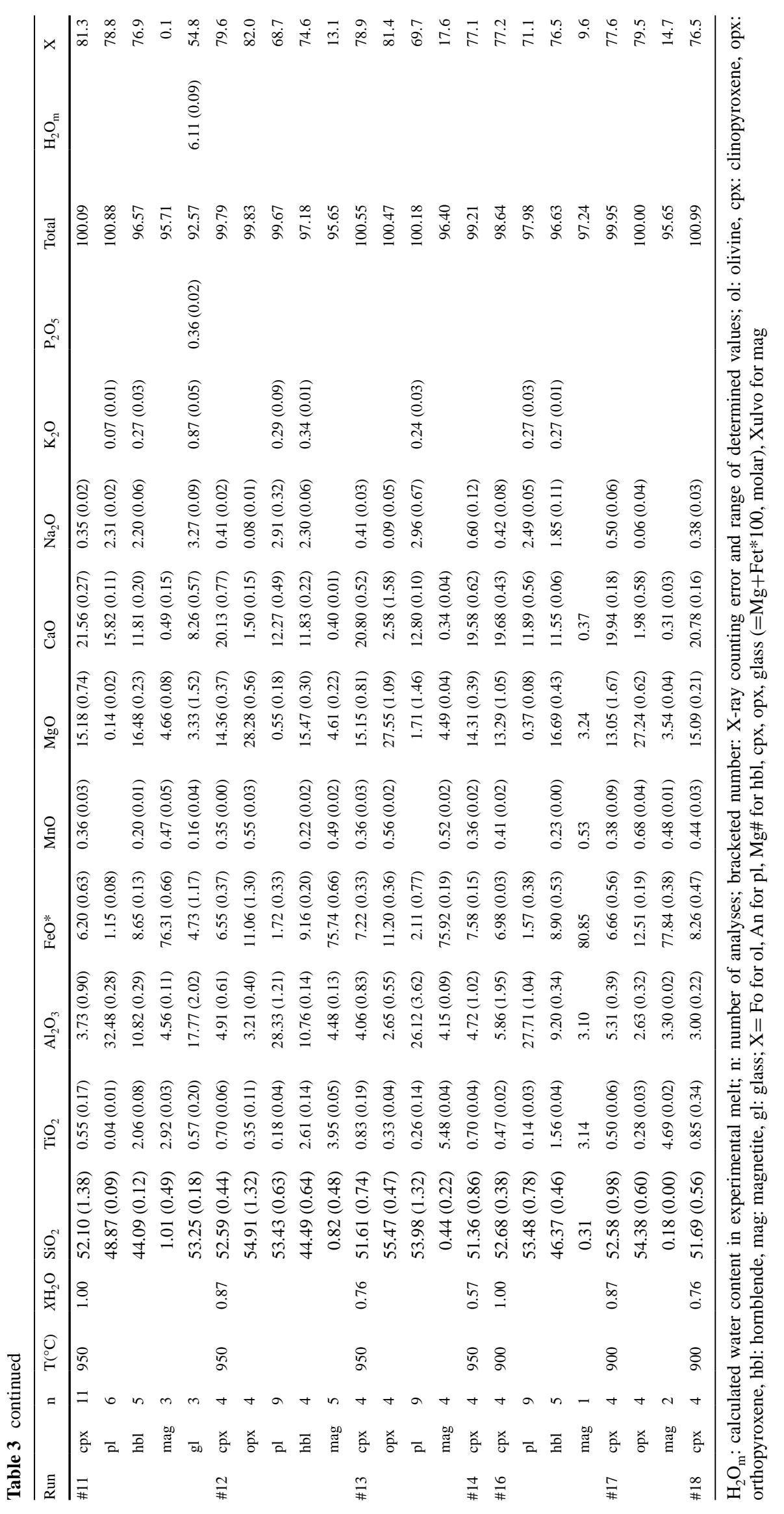




\section{Discussion}

Pre-eruptive conditions of basaltic tephra used for experiments

Several features of Arenal eruptive products point to very water-rich magmas. Arenal tephras are coarsely porphyritic, with An-rich plagioclase, clinopyroxene, orthopyroxene, olivine, spinel and hornblende in the early stage of eruption cycles. The continuous gas emissions by passive degassing and during explosive eruptions (e.g., WilliamsJones et al. 2001), producing fine-grained tephras also indicate that large quantities of volatiles are released to the atmosphere.

At the investigated pressure of $200 \mathrm{MPa}$, the mineral assemblage of the natural sample used for the experiments were reproduced experimentally for relatively water-rich conditions and constrain the pre-eruptive conditions of basaltic magmas at $1,000-1,050{ }^{\circ} \mathrm{C}$ and for water content $>4 \mathrm{wt} \%$ in basaltic andesitic melt ( $55 \mathrm{wt} \%$ $\mathrm{SiO}_{2}$ ) (Figs. 4, 5). The experimental pressure for olivine + clinopyroxene + magnetite crystallization agrees with previous experimental works on basaltic andesite, since $\mathrm{P}$ increase would destabilize olivine in basaltic andesite (e.g., Almeev et al. 2013). The strong influence of temperature and $\mathrm{H}_{2} \mathrm{O}_{\text {melt }}$ on crystal proportion (Fig. 5) allows us to constrain the temperature at $1,000{ }^{\circ} \mathrm{C}$ and 4.5-5 wt $\% \mathrm{H}_{2} \mathrm{O}\left(\mathrm{XH}_{2} \mathrm{O}_{\text {in }}=0.8\right)$ for the crystal-poor basalt. Clinopyroxene and olivine phenocrysts have high wollastonite and forsterite component, respectively, both in equilibrium in basaltic magma with $\mathrm{H}_{2} \mathrm{O}_{\text {melt }}$ of 4-5 wt\% (Figs. 7, 8). The highest Fo content in natural olivine $\left(\mathrm{Fo}_{92}\right)$ has not been reproduced in the experimental products but could be expected to be obtained at high temperature $\left(1,050{ }^{\circ} \mathrm{C}\right)$, close to the clinopyroxene stability curve and at $\mathrm{XH}_{2} \mathrm{O}_{\text {in }} \sim 0.8\left(\mathrm{H}_{2} \mathrm{O}_{\text {melt }}=4 \mathrm{wt} \%\right)$ (Fig. 4). Plagioclases are present as microlites in the matrix and their An contents (up to $\mathrm{An}_{86}$ ) indicate crystallization at slightly lower temperature and/or higher water content $\left(1,000-950{ }^{\circ} \mathrm{C}\right.$ and $\left.4-6 \mathrm{wt} \% \mathrm{H}_{2} \mathrm{O}_{\text {melt }}\right)$ than the crystallization temperature of olivine and clinopyroxene, which is consistent with a crystallization of these microlites during magma ascent. Similarly, spinel crystals in the natural basalt are microcrysts occurring in groundmass and their concentration in $\mathrm{MgO}$ and $\mathrm{Al}_{2} \mathrm{O}_{3}$ are lower than in the experimental spinel, suggesting a late crystallization during ascent (Fig. 9). The oxygen fugacity can be estimated using the composition of Fe-bearing phases (i.e., olivine, spinel and clinopyroxene). Fo of olivine, Mg\# of clinopyroxene and the ulvöspinel component in natural spinel all suggest oxidized redox conditions between $\mathrm{NNO}+1.5$ and 2 (Figs. 6, 7, 8).
Inferences for the magmatic conditions at Arenal

The composition of our phenocryst-poor basalt magma used for experiments is close to the most mafic tephras and lava flows erupted throughout Arenal's eruptive history (e.g., ET3-1, 930 BP (Figs. 1c, 10) and ET6 (1,250 BP); Bolge et al. 2006; Soto and Alvarado 2006; this study). Using this basalt as starting material, the experimental products allow us to determine an experimentally derived liquid line of descent (LLD) that we can compare to the natural trends of all magma compositions of Arenal. Our experimental LLD is in good agreement with observed compositional ranges with some notable exceptions. The experimental LLD indicates slightly higher concentrations but generally parallel to the trend of natural samples in components that were also slightly higher in the starting composition, namely $\mathrm{TiO}_{2}, \mathrm{P}_{2} \mathrm{O}_{5}$ and $\mathrm{K}_{2} \mathrm{O}$. The experimental LLD for $\mathrm{P}_{2} \mathrm{O}_{5}$ at conditions at which apatite is not stable (above $900{ }^{\circ} \mathrm{C}$ ), while generally parallel to the trend of natural samples, indicate a more pronounced enrichment in $\mathrm{P}_{2} \mathrm{O}_{5}$ than the natural trend. The offset on the mafic end can be explained by the higher initial $\mathrm{P}_{2} \mathrm{O}_{5}$ concentration but the smaller enrichment in the natural samples over the course of evolution from basalt to $\sim$ dacite needs explanation. The $\mathrm{P}_{2} \mathrm{O}_{5}$ content of the experimental melts reflect concentration levels as expected from a nearly perfectly incompatible element. The starting composition contains 0.24 wt $\% \mathrm{P}_{2} \mathrm{O}_{5}$ while the most silicic experimental melt contains $0.43-0.50 \mathrm{wt} \%$ suggesting a crystal content of 44 $52 \%$ which is indeed observed (Fig. 5). This is consistent with apatite not being present (except in one run) and thus indicates that apatite does not crystallize at the observed crystallinity and the pre-eruptive temperatures of $950{ }^{\circ} \mathrm{C}$ and above. Therefore, lower $\mathrm{P}_{2} \mathrm{O}_{5}$ of the natural samples would either suggest lower temperatures where apatite would be stable, or that $\mathrm{P}_{2} \mathrm{O}_{5}$ was buffered at lower concentrations by open-system processes through assimilation of crustal material or mixing with silicic melts that contain less P. We prefer open-system processes as explanation because of evidence of natural samples for such behavior (Reagan et al. 1987; Streck et al. 2002, 2005; Ryder et al. 2006).

$\mathrm{TiO}_{2}$ concentrations increase slightly along the experimental LLD but natural samples indicate a constant or slight decrease in $\mathrm{TiO}_{2}$ concentration with differentiation (Fig. 10). This again could suggest addition of lower $\mathrm{TiO}_{2}$ melt or crustal material contributing to a lower bulk rock $\mathrm{TiO}_{2}$ concentration. Ti-magnetite is ubiquitous in Arenal magmas therefore blending in more fractioned melts could easily lead to depletion of Ti. Again, we do not place significance on the vertical offset but in the slightly different trajectories of experimental LLD and natural rock data. 
Fig. 6 Variation of An content of experimental and natural plagioclase with a temperature and $\mathbf{b}$ initial fluid composition $\left(\mathrm{XH}_{2} \mathrm{O}_{\text {in }}\right)$. Numbers in italic are $\mathrm{H}_{2} \mathrm{O}$ content in glass (wt\%). Natural plagioclases are microcrystals in the matrix. Arrows are for highest values for plagioclase in natural samples (this study)
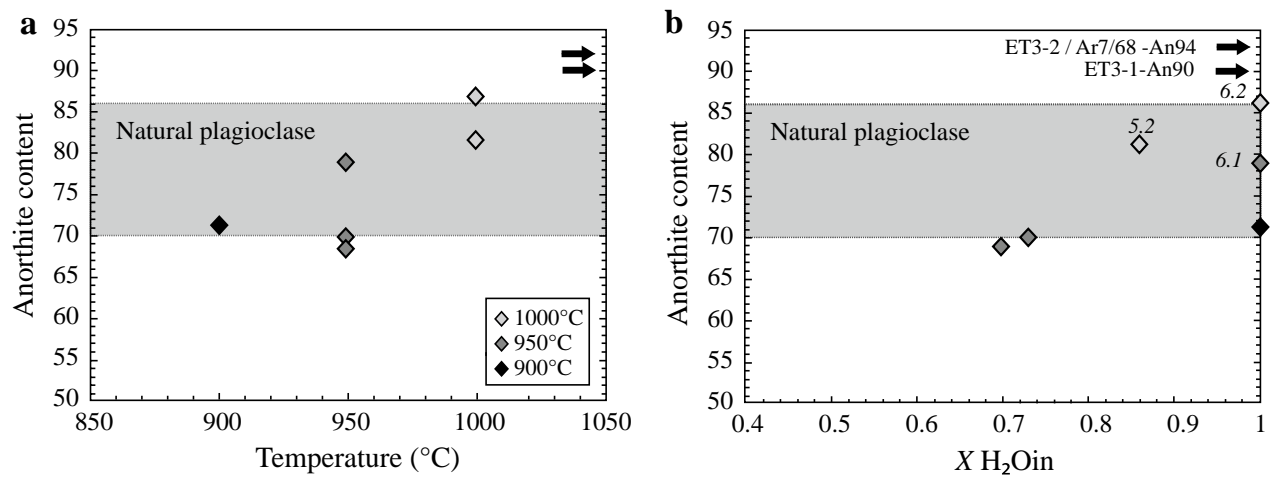

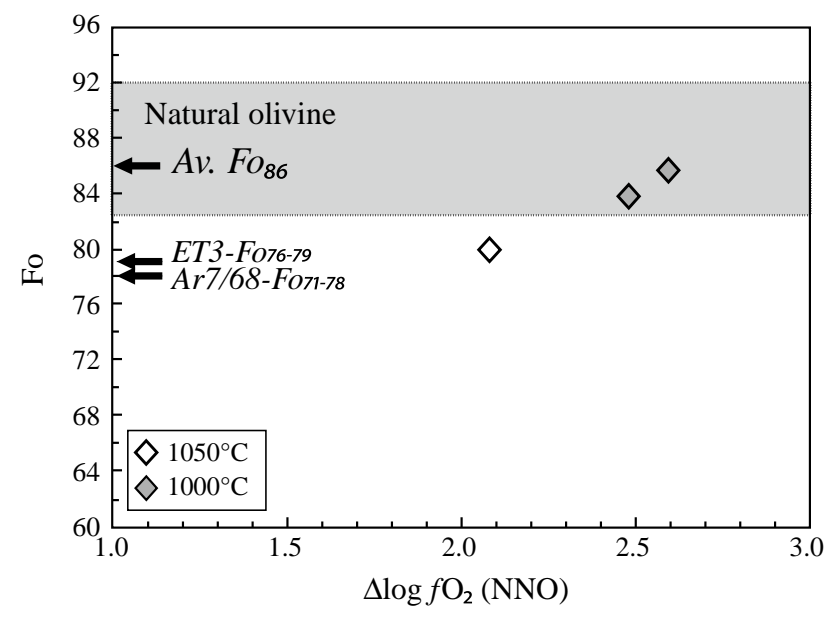

Fig. 7 Variation of forsterite content in olivine with oxygen fugacity. Forsterite content in natural olivine (MJS05) ranges from $\mathrm{Fo}_{82}$ to $\mathrm{Fo}_{92}$ (average $\mathrm{Fo}_{86}$ ). Arrows are for highest values for olivine in natural samples [ET3 from Wade et al. (2006) and Ar7/68 from Streck et al. (2005)]

Interestingly, the trends for $\mathrm{P}$ and Ti defined by experimental data are more consistent with data on melt inclusions in olivine (Wade et al. 2006).

$\mathrm{CaO}$ and $\mathrm{MgO}$ concentrations in the experimentally produced melts are on the high end of the natural data array but $\mathrm{Al}_{2} \mathrm{O}_{3}$ concentrations are on the lower side until about $\sim 57 \mathrm{wt} \% \mathrm{SiO}_{2}$ (Fig. 10). We believe these features may be used to explain the processes leading to the rather enigmatic two compositional groups of samples at Arenal volcano, known as low- and high- $\mathrm{Al}_{2} \mathrm{O}_{3}$ with approximately average $\mathrm{Al}_{2} \mathrm{O}_{3}$ concentrations of 18.5 and $20.5 \mathrm{wt} \%$, respectively (Borgia et al. 1988; Bolge et al. 2006). Initially, high and low- $\mathrm{Al}_{2} \mathrm{O}_{3}$ groups where defined by Borgia et al. (1988) for a narrow composition range around $55 \mathrm{wt} \% \mathrm{SiO}_{2}$ (Fig. 10). With more data available what used to be distinct fields is now a gradational array (Fig. 10). Although gradational, using an arbitrary boundary at $20 \mathrm{wt} \%$ to distinguish between low and high-Al samples, distinct compositional trends can be discussed. No trace-element or other differences between low- and high- $\mathrm{Al}_{2} \mathrm{O}_{3}$ samples have been noted (Bolge et al. 2006). Thus, these compositional groups are unlikely related to distinct parental magmas that could have arisen from differences in magma generation processes in the mantle wedge but rather are the result of processes occurring in the crust. Our starting basalt composition is a low $\mathrm{Al}_{2} \mathrm{O}_{3}$ magma, and we are confident that this is a mantle-derived feature (Fig. 10). Crystal (plagioclase) accumulation is unlikely as samples with high $\mathrm{Al}_{2} \mathrm{O}_{3}$ are not consistently low in $\mathrm{CaO}$; in this hypothesis, a positive correlation would be expected. We believe the key diagram that constrains the likely processes responsible for high vs. low- $\mathrm{Al}$ magmas is $\mathrm{Al}_{2} \mathrm{O}_{3}$ versus $\mathrm{MgO}$ (Fig. 11). As expected, our starting composition is among the most primitive samples that all have low $\mathrm{Al}_{2} \mathrm{O}_{3}$. As $\mathrm{MgO}$ starts to decrease, $\mathrm{Al}_{2} \mathrm{O}_{3}$ increases slightly until about $\sim 4 \mathrm{wt} \% \mathrm{MgO}$ beyond which it decreases in the lowAl samples and increases rapidly in the high-Al samples. The trend of low-Al samples illustrates a fractionation trend that is consistent with an initial crystallization that starts out without or with little plagioclase leading to $\mathrm{Al}$ to behave as mildly incompatible element. Only at lower $\mathrm{Mg}$ contents, the amount of plagioclase is high enough leading to a decrease in Al. On the other hand, high-Al samples indicate continued and stronger increase in $\mathrm{Al}$ than in low-Al samples suggesting that plagioclase did not crystallize. Both scenarios could take place with the same hydrous parental magma. One time it crystallizes under lower pressure while in the other case, crystallization takes place under higher pressure suppressing plagioclase crystallization more strongly (e.g., Sisson and Grove 1993; Almeev et al. 2013). In both environments, clinopyroxene crystallizes as suggested by decreasing $\mathrm{Sc}$ contents in low as well as in high-Al samples (Fig. 11).

There is also petrographic evidence that this occurred. Streck et al. (2005) identified a high-pressure crystallization environment based on a distinct mineral assemblage with Al-rich clinopyroxene but without plagioclase (see below). Our experiments reproduce lower pressure upper crustal conditions where plagioclase begins to crystallize less than $50{ }^{\circ} \mathrm{C}$ below the crystallization temperature of pyroxene, olivine and Ti-magnetite (Fig. 4) and it explains 
Fig. 8 Composition of clinopyroxene versus a water content in glass and $\mathbf{b}$ oxygen fugacity. Arrows are for highest values for clinopyroxene in natural samples [this study and Streck et al. (2005)]
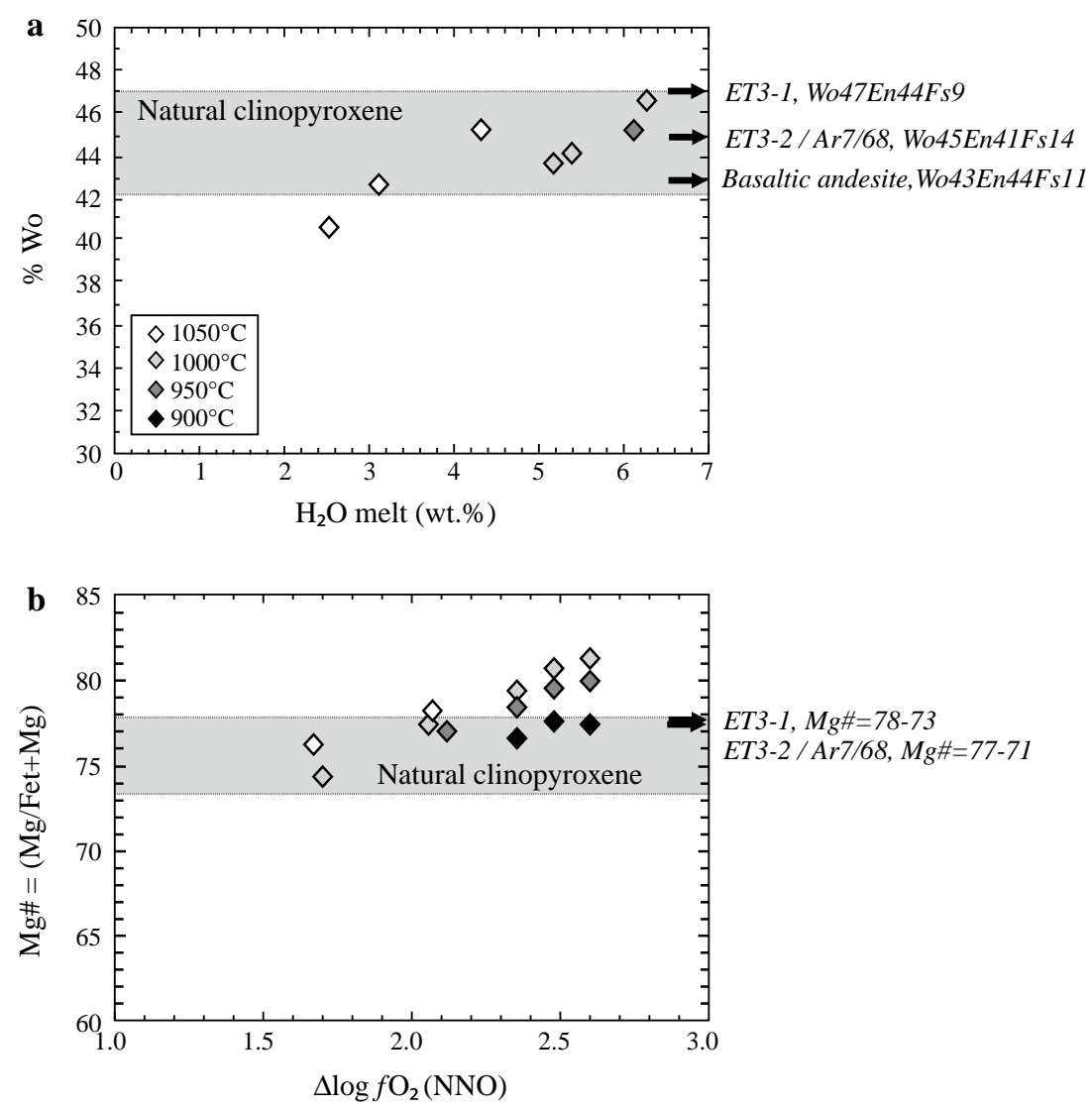

well why the experimental liquid compositions remain on the low-Al trend. Incompatible trace-element evolution would be similar under both conditions. In this regard, we also like to note that the observed mineral assemblage of a high-Al basalt does not necessarily need to be diagnostic of a deep crystallization because the observed minerals can be overprinted by additional shallow crystallization processes prior to the eruption. For example, sample ET3-1 (Fig. 1; Table 1) has a composition very close to the crystal-poor basalt MJS05-SCPN but is a high $\mathrm{Al}_{2} \mathrm{O}_{3}$ sample and with low $\mathrm{Cr}$ (41 ppm) (no Sc concentrations are available) (Fig. 10; Table 1). This sample contains 15 vol\% of phenocrysts with abundant plagioclase, clinopyroxene, orthopyroxene and spinel. The presence of plagioclase, orthopyroxene and spinel phenocrysts and the absence of olivine, as well as the high crystal content, and the composition of plagioclase $\left(\mathrm{An}_{90}\right)$, clinopyroxene $(\mathrm{Mg} \#=73-78$, $\left.\mathrm{Wo}_{47} \mathrm{En}_{44} \mathrm{Fs}_{49}\right)$, orthopyroxene $(\mathrm{Mg \#}=77)$ and spinel constrain crystallization of this assemblage to slightly lower temperature and lower $\mathrm{H}_{2} \mathrm{O}_{\text {melt }}$ than crystal-poor basalt at $1,000-1,025{ }^{\circ} \mathrm{C}$ and $4 \mathrm{wt} \% \mathrm{H}_{2} \mathrm{O}_{\text {melt }}\left(\mathrm{XH}_{2} \mathrm{O}_{\text {in }}=0.6-0.7\right)$, respectively (Figs. 4 5, 6,7, 8, 9, ET3-1).

Other evidence for minerals derived from crystallization at various pressures is based on the interpretation of melt inclusion data. The water content estimated from clinopyroxene and olivine-hosted melt inclusions in historic basalts ranges from 1 to $5.5 \mathrm{wt} \%$ [average 3.6 and 4.4 for melt inclusions in clinopyroxene and olivine, respectively, of ET3; Wade et al. (2006, 2008)] and corroborate experimental observations (Fig. 12). Wade et al. (2006) proposed that the observed increase of water content with decreasing $\mathrm{Mg \#}$ in clinopyroxene reflects isobaric, $\mathrm{H}_{2} \mathrm{O}$-undersaturated crystallization, where $\mathrm{H}_{2} \mathrm{O}$ increases in the melt as crystallization proceeds, whereas melt inclusions in olivine record polybaric ascent-driven crystallization $\left(\mathrm{H}_{2} \mathrm{O}_{\text {melt }}\right.$

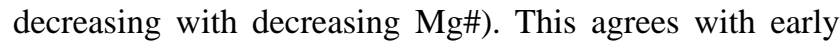
clinopyroxene crystallization followed by olivine crystallization $\left(\mathrm{Fo}_{79}\right)$ from water-rich basaltic melt with 4-5 wt\% $\mathrm{H}_{2} \mathrm{O}$ (Fig. 4). The most primitive melt inclusions in basaltic tephra are high alumina basaltic liquids with composition very close to our starting composition (MJS05-SCPN; $51 \mathrm{wt} \% \mathrm{SiO}_{2}, 19-20 \mathrm{wt} \% \mathrm{Al}_{2} \mathrm{O}_{3}$, Figs. 10, 12).

Magma history of basaltic andesite of 1968-2010 eruptions

Although the bulk composition of the basaltic andesites that erupted at Arenal for 42 years from 1968 to 2010 shows minimal compositional variations (Fig. 10), particularly from 1970 onward (Streck et al. 2005; Ryder et al. 2006), the mineral compositions record a complex magma history 
Fig. 9 Variation of magnetite composition in experimental runs and natural tephra from Arenal (this study and Streck et al. 2002). a ulvöspinel content vs. oxygen fugacity, and $\mathbf{b}$ $\mathrm{MgO}$ versus $\mathrm{TiO}_{2}$ (wt $\%$ )
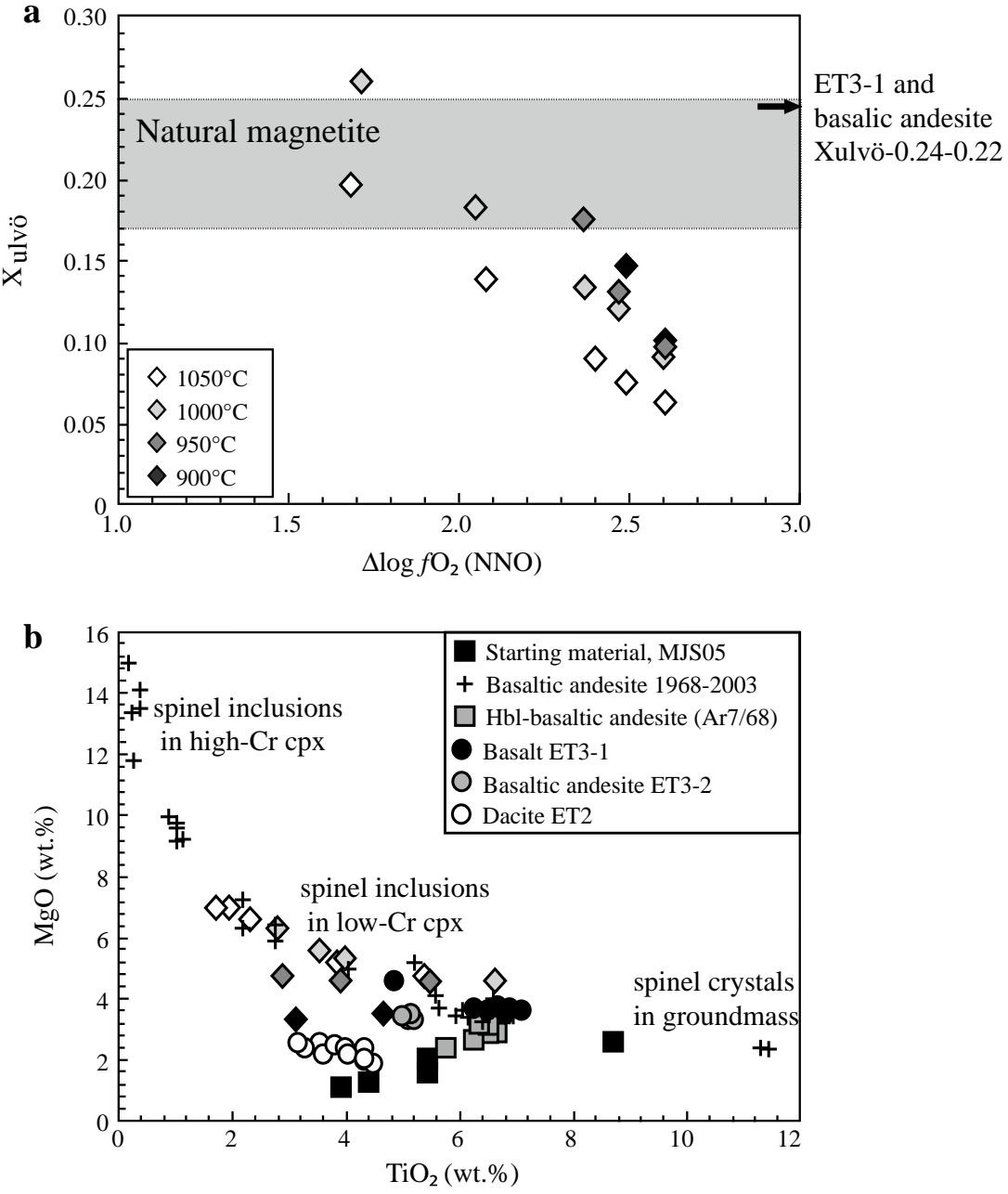

(Streck et al. 2002; 2005). The results of our phase equilibria experiments can be used to address previously postulated crystallization environments beneath Arenal deduced from natural rocks (Streck et al. 2005) and to revisit petrogenetic scenarios of basaltic andesites in general.

As expected, the results of our experiments show clearly a strong influence of temperature and water content on phase equilibria and crystal proportion. The mineralogy of the crystal-poor basaltic andesite of the early stage (e.g., Ar7/68 with clinopyroxene-orthopyroxeneplagioclase-magnetite \pm hornblende \pm olivine, 7 vol\% phenocrysts, Fig. 1b; Table 1) is consistent with waterrich basaltic andesitic magma stored at relatively high temperature prior to the eruption, whereas the basaltic andesites with high crystal content (plagioclase-clinopyroxene-orthopyroxene-magnetite \pm olivine, up to 35 vol\%, Fig. 1a) suggest lower temperature and/or lower water content. The latter conditions correspond with the mineral assemblage and compositions of the dominant environment (plagioclase + clinopyroxene + orthopyroxene + Ti-magnetite) (Streck et al. 2005) which formed after fractional crystallization of basaltic magmas. In addition to the dominant environment, observed mineral associations allowed Streck et al. (2005) to define three minor crystallization environments. Minor environment I corresponds well with experimental conditions of early crystallization of water-rich basaltic magmas $\left(3-4 \mathrm{wt} \% \mathrm{H}_{2} \mathrm{O}\right)$ to crystallize Mg-richer olivine (Fo78-81) and clinopyroxene $\left(\mathrm{Mg} \#=78-85\right.$, up to $\left.6 \mathrm{wt} \% \mathrm{Al}_{2} \mathrm{O}_{3}, \mathrm{Wo}_{43}\right)$ during a temperature interval of $1,050-1,100{ }^{\circ} \mathrm{C}$ and oxidizing conditions $\left(\Delta \log f \mathrm{O}_{2}=\mathrm{NNO}+2-2.5\right)$ (Figs. 8, 9; Table 3). Rare $\mathrm{Fo}_{91}$ olivine found in 1968-2010 basaltic andesites (Streck et al. 2005) is also present in our starting basalt and further supports the inference that minor environment I reflects conditions during basaltic recharge below Arenal.

Among Arenal eruptive products, the characteristic association of low-Fo $\left(\mathrm{Fo}_{71}\right.$ to $\left.\mathrm{Fo}_{78}\right)$ olivine and An-rich plagioclase but without orthopyroxene is occasionally observed and was named minor environment II (Streck et al. 2005). This mineralogical assemblage is reproduced experimentally at higher water content, leading to the crystallization of olivine at the expense of orthopyroxene. At $1,000{ }^{\circ} \mathrm{C}$, 
Fig. 10 Composition of experimental glasses and natural tephras and lavas from Arenal. Basaltic andesite (1968-2003) from Ryder et al. (2006) and Streck et al. (2002). Large circles are old tephra: ET3-1, ET3-2, and ET2 (see text). Small circles are melt inclusions in ET3 and ET6 normalized to $100 \%$ anhydrous with $\mathrm{FeO}$ as FeOt (Wade et al. 2006). HAG and LAG: high- and low-alumina group, respectively from Borgia et al. (1988)
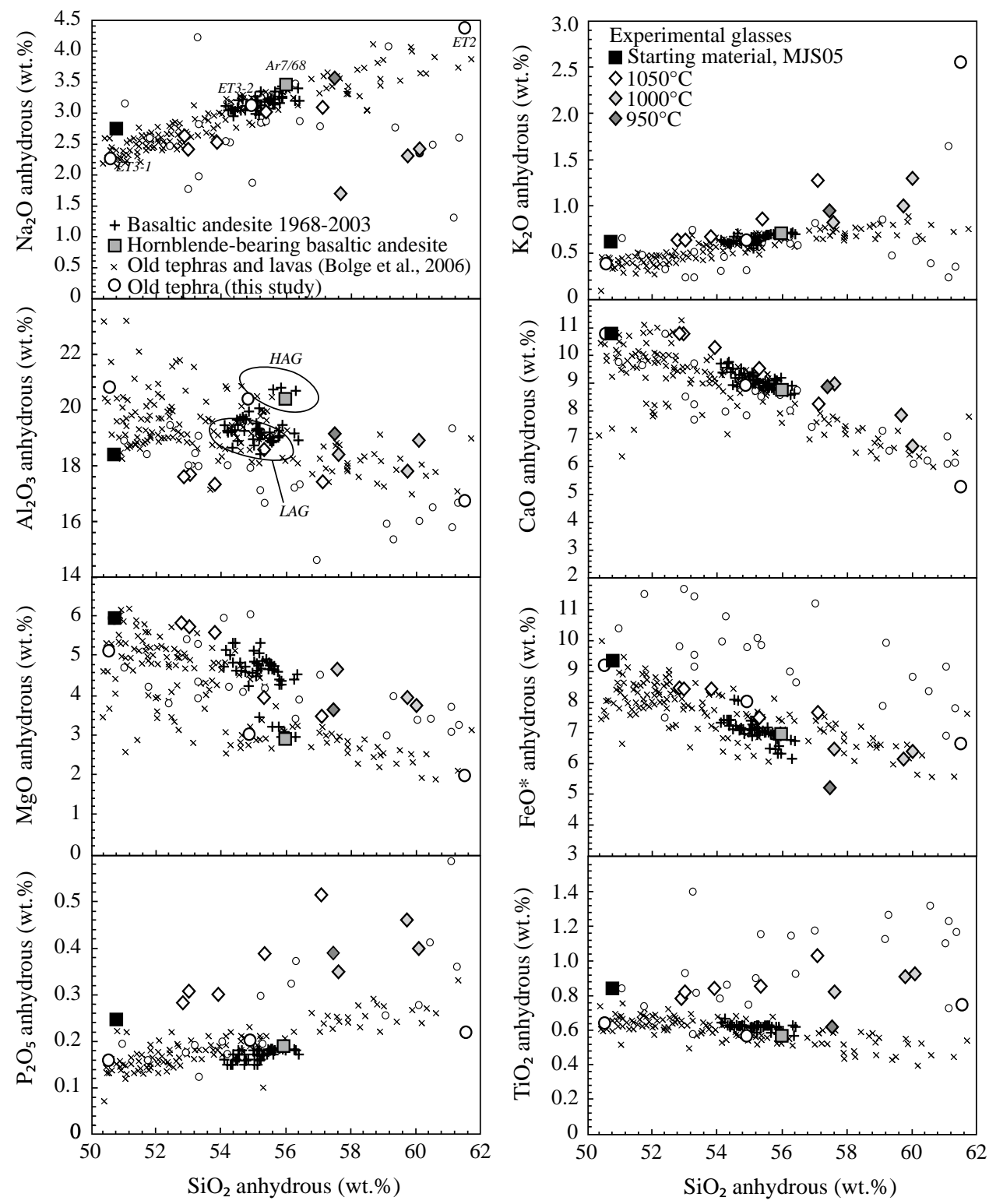

this reaction occurs when the water content of the melt reaches 5-6 wt $\% \mathrm{H}_{2} \mathrm{O}$ (Fig. 4). Spinel inclusions in low-Cr clinopyroxene are titanomagnetite and their compositions corroborate crystallization at high-temperature $(1,000$ $1,050{ }^{\circ} \mathrm{C}$ ) and oxidized conditions (Fig. 9). We reproduce the mineralogical assemblage but not the compositions of phases of minor environment III (clinopyroxene + Timagnetite \pm olivine, no plagioclase, Streck et al. 2005) at high temperature (above $1,000-1,050{ }^{\circ} \mathrm{C}$; Fig. 4). Low $\mathrm{Mg} \#$ of natural clinopyroxene of this environment suggests more evolved melt compositions than achieved experimentally at high temperature. This in turn suggests that this plagioclase-free assemblage is not characteristic for high temperature (Fig. 4) but rather for higher pressure than our experimental conditions of $200 \mathrm{MPa}$. It is this environment that likely leads to the high-Al trend (Fig. 11). Also,
Cr-Al-rich chromites observed in basaltic andesite have not been reproduced experimentally (Fig. 9).

Continuous degassing of Arenal volcano during the 19682010 eruption and existing mineral and melt inclusion data (Streck and Wacaster 2006) suggest that evolution of basaltic magmas to more evolved magmas is taking place under fluid-saturated conditions but at variable water activities. Our experiments, which are all performed at fluid-saturated conditions, indicate that a decrease of temperature induces the change of the mineral assemblage clinopyroxene + olivine + magnetite (e.g., MJS05-SCPN) to clinopyroxene + orthopyroxene + plagioclase + magnetite as observed in basaltic tephra (e.g., ET3-1). The interstitial melt evolves to basaltic andesitic composition at the time of this change in crystallization assemblage (Fig. 10). However, at the investigated pressure, this evolution can only be reproduced at 
Fig. 11 Variation of $\mathbf{a} \mathrm{Al}_{2} \mathrm{O}_{3}$ versus $\mathrm{MgO}, \mathbf{b ~ A l} \mathrm{O}_{3}$ versus $\mathrm{SiO}_{2}, \mathbf{c ~ S c}$ versus $\mathrm{SiO}_{2}$ and $\mathbf{d ~ S c}$ versus $\mathrm{MgO}$ content in basaltic tephra MJS05-SCPN (black square) and Arenal lavas and tephras (diamonds) from Bolge et al. (2006)
Fig. 12 Water content versus a silica and $\mathbf{b}$ potassium content in experimental glasses and natural melt inclusions. Open circles are melt inclusions in olivine from ET3 basalt (Wade et al. 2006); open triangles are melt inclusions in clinopyroxene and plagioclase from 1968 basaltic andesite (Streck and Wacaster 2006)
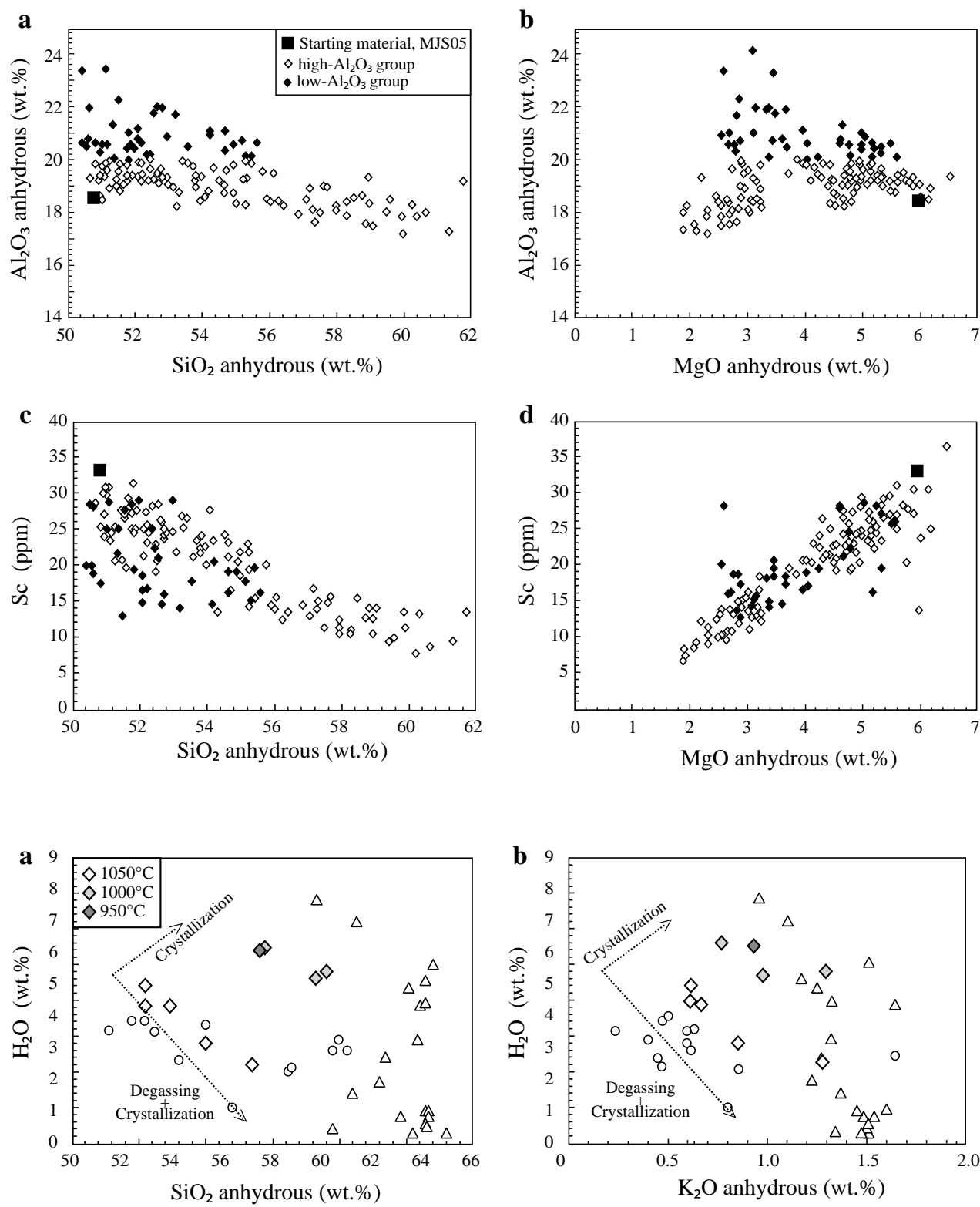

water activities below $1\left(\mathrm{H}_{2} \mathrm{O}_{\text {melt }}\right.$ between 3 and $\left.5 \mathrm{wt} \%\right)$ since orthopyroxene was not stable at water-saturated conditions $\left(\mathrm{H}_{2} \mathrm{O}_{\text {melt }}\right.$ of $\left.\sim 5-6 \mathrm{wt} \%\right)$. In the framework of our experiments, basaltic andesite magma at Arenal (bulk rock composition) would represent fractionated residual liquids after a minimum of $15 \%$ crystallization (clinopyroxene + olivine + magnetite) of a basaltic magma at 1,050-1,000 ${ }^{\circ} \mathrm{C}, 200 \mathrm{MPa}$ and for a water content in the melt around 3-4 wt\% (run\#4, Table 3; Figs. 10, 12). In this sense, bulk compositions of crystal-rich basaltic andesites of the recent and earlier eruptions could represent liquid compositions (Ryder et al. 2006; Wade et al. 2006). However, the striking $\mathrm{Fe}-\mathrm{Mg}$ discordance between, for example, orthopyroxene and bulk compositions but concordance with melt inclusion data of crystal-rich basaltic andesites (Streck and Wacaster 2006) requires a more complicated scenario. Even though bulk compositions of basaltic andesites fall on the experimental LLD (Fig. 10), crystalrich natural magmas may have lost melt therefore moving the bulk composition back toward their basaltic parent along the trajectory of the LLD. Bolge et al. (2006) observe that as mafic magmas become crystal richer associated silicic magmas become crystal poorer from which they inferred the rise of a differentiated melt from a mafic magma into an overlying more silicic magma. Streck and Wacaster (2006) also proposed that phenocryst-poor silicic magmas are the result of melt extraction from basaltic andesite based on compositional similarity of melt inclusions with silicic tephras. The process of loosing melt would be difficult to decipher from the 
composition of the basaltic andesites alone yet would explain that most ferromagnesian silicates were in equilibrium with more evolved liquids like those recorded in melt inclusions (Streck and Wacaster 2006).

Basaltic andesites of the recent 1968-2010 eruption are mostly low-Al magmas with $18.5-19.5 \mathrm{wt} \% \mathrm{Al}_{2} \mathrm{O}_{3}$ except for the very early part of the eruption (1968-1969) when magmas contain distinctly higher $\mathrm{Al}_{2} \mathrm{O}_{3}$ with values above $20 \mathrm{wt} \%$ (Reagan et al. 1987; Ryder et al. 2006). Using high-Al as signal of deep crystallization (see above), this would suggest that the first magmas of the 1968-2010 eruption evolved deeper in the crust and that ascent was relatively fast leaving little time for significant compositional overprint by shallower level crystallization. Ascent of these magmas was likely induced by recharge with basaltic magma of which evidence is found in mineral assemblage of minor environment I (Streck et al. 2002; 2005).

Relatively more evolved andesitic-dacitic tephra erupted sporadically in a few historic eruptions [i.e., ET2: 1525 A.D. radiocarbon age from Melson and Saenz (1973)] (Borgia et al. 1988; Bolge et al. 2006). The bulk rock compositions of such evolved tephra are on the LLD of our basaltic magma at low temperature (e.g., ET2, Fig. 10 and Table 1). Finding comparable andesitic melt inclusions in plagioclase and clinopyroxene of basaltic andesite, Streck and Wacaster (2006) suggested that fractional crystallization of basaltic andesitic magmas produced such evolved liquids rather than a single state fractionation event of basaltic magma.

\section{Conclusion}

This study provides constraints on the pre-eruptive conditions of basaltic magma at Arenal volcano, the magmatic evolution toward more evolved compositions, and the different crystallization environments preserved in the mineralogy of erupted basaltic andesites of the recent 1968-2010 as well as earlier eruptions. Basaltic magmas are waterrich $\left(4.5-5 \mathrm{wt} \% \mathrm{H}_{2} \mathrm{O}\right)$ and crystallize small amounts of olivine, clinopyroxene and magnetite phenocrysts $(<5$ vol\%) at $1,000-1,050{ }^{\circ} \mathrm{C}, 200 \mathrm{MPa}$ and oxidizing condition (NNO + 1.5-2). The residual melt at these conditions is basaltic andesite $\left(55 \mathrm{wt} \% \mathrm{SiO}_{2}\right)$ and the composition mostly matches the composition of natural basaltic andesite observed at Arenal under fluid-saturated conditions but variable water activities.

At $1,000{ }^{\circ} \mathrm{C}$ and $200 \mathrm{MPa}$, a decrease of water content by approximately $1 \mathrm{wt} \%$ induces significant changes in the mineral assemblage from olivine + clinopyroxene + plagioclase ( $5 \mathrm{wt} \% \mathrm{H}_{2} \mathrm{O}$ in the melt) to clinopyroxene + plagioclase + orthopyroxene $\left(4 \mathrm{wt} \% \mathrm{H}_{2} \mathrm{O}\right.$ in the melt) and match observed mineral assemblages in crystal-rich basalt ( $\geq 15$ vol\%) and basaltic andesitic tephras and lava flows.
The lack of orthopyroxene and the presence of amphibole, as also observed in basaltic andesitic tephra units of earlier eruptive phases, further indicate nearly water-saturated conditions at temperature lower than $950{ }^{\circ} \mathrm{C}$.

The compositions of the experimental melts generally reproduce the compositional trends of the natural rock suite indicating that phase assemblages and compositions crystallizing at $\sim 200 \mathrm{MPa}$ are indeed controlling the natural LLD. Exceptions are $\mathrm{P}$ and Ti which have higher concentrations than observed in the natural suite and are best explained by open-system processes (contamination or assimilation of Ti- and P-poor continental crust) affecting the natural compositions. In light of our experimental results, that reflect liquid evolution at upper crustal conditions, the two compositional groups at Arenal previously known as low- and high- $\mathrm{Al}_{2} \mathrm{O}_{3}$ group (Borgia et al. 1988) are most likely the result of crystallization in the crust under low- and higher pressure conditions, respectively. Using high-Al as signal of deeper crystallization, the first magmas of the 1968-2010 eruption evolved deep in the crust and ascent was relatively fast leaving little time for significant compositional overprint by shallower level crystallization. Continuous degassing may contribute to persistent small-scale explosive activity-so characteristic for the recent eruption and was promoted by crystallization of the water-rich magmas at Arenal.

Acknowledgments We would like to thank Katrin Hug and Melanie Schrage from the University of Freiburg and Christophe Nevado from the University of Montpellier for experimental and technical assistance during sample preparations. We thank Pavel Izbekov and Georg Zellmer for technical reviews and helpful suggestions that improved the quality of the paper and Jochen Hoefs for editorial handling. Research of this project was supported by German Science Foundation (DFG) Grant PA 1804/1-1.

\section{References}

Almeev R, Holtz F, Ariskin AA, Kimura J-I (2013) Storage conditions of Bezymianny Volcano parental magmas: results of phase equilibria experiments at 100 and $700 \mathrm{MPa}$. Contrib Miner Petrol 166:1389-1414

Berndt J, Liebske C, Holtz F, Freise M, Nowak M, Ziegenbein D, Hurkuck W, Koepke J (2002) A combined rapid-quench and $\mathrm{H}_{2}$-membrane setup for internally heated pressure vessels: description and application for water solubility in basaltic melts. Am Miner 87:1717-1726

Bolge LL, Carr MJ, Feigenson MD, Alvarado GE (2006) Geochemical stratigraphy and magmatic evolution at Arenal Volcano, Costa Rica. J Volcanol Geoth Res 157:34-48

Borgia A, Poore C, Carr MJ, Melson WG, Alvarado GE (1988) Structural, stratigraphic, and petrologic aspects of the Arenal-Chato volcanic system, Costa Rica: evolution of a young stratovolcanic complex. Bull Volcanol 50:86-105

Botcharnikov RE, Koepke J, Holtz F, McCammon C, Wilke M (2005) The effect of water activity on the oxidation and structural state of $\mathrm{Fe}$ in a ferrobasaltic melt. Geochim Cosmochim Acta 69(21):5071-5085 
Cigolini C (1998) Intracrustal origin of Arenal basaltic andesite in the light of solid-melt interactions and related compositional buffering. J Volcanol Geoth Res 86:277-310

Devine JD, Gardner JE, Brack HP, Layne GD, Rutherford MJ (1995) Comparison of microanalytical methods for estimating $\mathrm{H}_{2} \mathrm{O}$ contents of silicic volcanic glasses. Am Miner 80:319-328

Freise M, Holtz F, Nowak M, Scoates JS, Strauss H (2009) Differentiation and crystallization conditions of basalts from the Kerguelen large igneous province: an experimental study. Contrib Miner Petrol 158:505-527

Iacono-Marziano G, Yann Morizet Y, Le Trong E, Gaillard F (2012) New experimental data and semi-empirical parameterization of $\mathrm{H} 2 \mathrm{O}-\mathrm{CO} 2$ solubility in mafic melts. Geochim Cosmochim Acta 97:1-23

Koepke J (1997) Analyse von wasserhaltigen silikatischen Gläsern mit der Mikrosonde: wassergehalte und Alkaliverluste. Beih. J. Miner 9:200

Leake BE, Woolley AR, Arps CES, Birch WD, Gilbert MC, Grice JD, Hawthorne FC, Kato A, Kisch HJ, Krivovichev VG, Linthout K, Laird J, Mandarino JA, Maresch WV, Nickel EH, Rock NMS, Schumacher JC, Smith DC, Stephenson NCN, Ungaretti L, Whittaker EJW, Youzhi G (1997) Nomenclature of amphiboles: report of the subcommittee on amphiboles of the international mineralogical association, commission on new minerals and mineral names. Am Miner 82:1019-1037

Malavassi E, Schwartz SY, Hagerty MT, Fernandez E, Duarte E, Barboza V, Saenz R, Melson W, Baquero J (1998) The Cinco de Mayo eruption: commemorating 30 years of continuous activity of Arenal volcano, Costa Rica. AGU abstract, Fall ' 89 meeting

Melson WG (1984) Prehistoric eruptions of Arenal Volcano, Costa Rica. Vinculos 10:34-59

Melson WG, Saenz R (1973) Volume energy and cyclicity of eruptions of the Arenal Volcano, Costa Rica. Bull Volcanol 37:416-437

Melson WG, James S, Barquero J (1999) Analysis of eruption trends, Arenal volcano, Costa Rica, 1995-1998: difficulties in long-term eruption forecasts. AGU abstract, Spring '99 meeting

Petermann M, Lundstrom CC (2006) Phase equilibrium experiments at $0.5 \mathrm{GPa}$ and $1100-1300^{\circ} \mathrm{C}$ on a basaltic andesite from Arenal volcano, Costa Rica. J Volcanol Geoth Res 157:222-235

Reagan M, Gill JB, Malavassi E, Garcia O, M M (1987) Changes in magma composition at Arenal volcano, Costa Rica, 1968-1985: real-time monitoring of open-system differentiaiton. Bull Volcanol 49:415-434

Ryder CH, Gill JB, Tepley F III, Ramos F, Reagan M (2006) Closedto open-system differentiation at Arenal volcano (1968-2003). J Volcanol Geoth Res 157:75-93
Schuessler JA, Botcharnikov RE, Behrens H, Misiti V, Freda C (2008) Oxidation state of iron in hydrous phono-tephritic melts. Am Miner 93(10):1493-1504

Shishkina TA, Botcharnikov RE, Holtz F, Almeev RR, Portnyagin MV (2010) Solubility of H2O- and CO2-bearing fluids in tholeiitic basalts at pressures up to $500 \mathrm{MPa}$. Chem Geol 277:115-125

Sisson TW, Grove TL (1993) Temperatures and H (sub 2) O contents of low-MgO high-alumina basalts. Contrib Miner Petrol 113(2):167-184

Soto GJ, Alvarado GE (2006) Eruptive history of Arenal volcano, Costa Rica, 7 ka to present. J Volcanol Geoth Res 157:254-269

Soto GJ, Alvarado GE, Ghigliotti M (1998) El registro eruptivo del Arenal en el lapso 3000-7000 anos antes del presente y nuevas deducciones sobre la edad del volcan. Bol. OSIVAM 9(17-18):19-49

Streck MJ, Wacaster S (2006) Plagioclase and pyroxene hosted melt inclusions in basaltic andesites of the current eruption of Arenal volcano, Costa Rica. J Volcanol Geoth Res 157:236-253

Streck MJ, Dungan MA, Malavassi E, Reagan M, Bussy F (2002) The role of basalt replenishment in the generation of basaltic andesites of the ongoing activity at Arenal volcano, Costa Rica: evidence from clinopyroxene and spinel. Bull Volcanol 64:316-327

Streck MJ, Dungan MA, Bussy F, Malavassi E (2005) Mineral inventory of continuously erupting basaltic andesites at Arenal volcano, Costa Rica: implications for interpreting monotonous, crystal-rich, mafic arc stratigraphies. J Volcanol Geoth Res 140:133-155

Szramek L, Gardner JE, Larsen J (2006) Degassing and microlite crystallization of basaltic andesite magma erupting at Arenal Volcano, Costa Rica. J Volcanol Geoth Res 157:182-201

Wade JA, Plank T, Melson WG, Soto GJ, Hauri E (2006) The volatile content of magmas from Arenal volcano. J Volcanol Geoth Res 157:94-120

Wade JA, Plank T, Hauri E, Kelley KA, Roggensack K, Zimmer M (2008) Prediction of magmatic water contents via measurement of $\mathrm{H} 2 \mathrm{O}$ in clinopyroxene phenocrysts. Geology 36(10):799-802

Webster JD, Holloway JR, Hervig RL (1987) Phase equilibria of a Be, $\mathrm{U}$ and F-enriched vitrophyre from Spor Mountain, Utah. Geochim Cosmochim Acta 51(3):389-402

Whitney JA (1972) The effect of reduced $\mathrm{H}_{2} \mathrm{O}$ fugacity on the buffering of oxygen fugacity in hydrothermal experiments. Am Miner 57(11-12):1902-1908

Williams-Jones AE, Stix J, Heiligmann M, Barquero J, Fernandez E, Gonzalez ED (2001) A model of degassing and seismicity at Arenal Volcano, Costa Rica. J Volcanol Geoth Res 108:121-139 